\title{
From structure topology to chemical composition. X. Titanium silicates: the crystal structure and crystal chemistry of nechelyustovite, a group III Ti-disilicate mineral
}

\author{
F. CÁmARA ${ }^{1, *}$ AND E. SOKOlOva ${ }^{2,3}$ \\ ${ }^{1}$ CNR - Istituto di Geoscienze e Georisorse, unità di Pavia, Via Ferrata 1, I-27100 Pavia, Italy \\ ${ }^{2}$ Department of Geological Sciences, University of Manitoba, Winnipeg, Manitoba R3T 2N2, Canada \\ ${ }^{3}$ Institute of Geology of Ore Deposits, Petrography, Mineralogy and Geochemistry, Moscow 119017, Russia
}

[Received 29 July 2009; Accepted 18 September 2009]

\section{ABSTRACT}

The crystal structure of nechelyustovite, ideally $\mathrm{Na}_{4} \mathrm{Ba}_{2} \mathrm{Mn}_{1.5} \square_{2.5} \mathrm{Ti}_{5} \mathrm{Nb}\left(\mathrm{Si}_{2} \mathrm{O}_{7}\right)_{4} \mathrm{O}_{4}(\mathrm{OH})_{3} \mathrm{~F}\left(\mathrm{H}_{2} \mathrm{O}\right)_{6}, a$

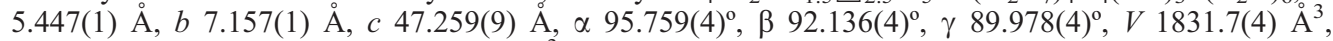
space group $P \overline{1}, Z=2, D_{\text {calc. }} 3.041 \mathrm{~g} \mathrm{~cm}^{-3}$, from Lovozero alkaline massif, Kola Peninsula, Russia, has been solved and refined to $R_{1}=13.9 \%$ on the basis of 1745 unique reflections $\left(F_{\mathrm{o}}>15 \sigma F\right)$. Electron microprobe analysis yielded the empirical formula $\left(\mathrm{Na}_{4.21} \mathrm{Mn}_{1.11}^{2+} \mathrm{Ca}_{0.46} \square_{1.22}\right)_{\Sigma 7.00}$ $\left(\mathrm{Ba}_{1.28} \mathrm{Sr}_{0.50} \mathrm{~K}_{0.30} \square_{0.92}\right)_{\Sigma 3.00}\left(\mathrm{Ti}_{4.14} \mathrm{Nb}_{1.43} \mathrm{Mn}_{0.33}^{2+} \mathrm{Fe}_{0.06}^{3+} \mathrm{Al}_{0.04}\right)_{\Sigma 6.00}\left(\mathrm{Si}_{8.03} \mathrm{O}_{28}\right) \mathrm{O}_{3.99}\left[(\mathrm{OH})_{2.94} \mathrm{~F}_{1.06}\right]_{\Sigma 4.00}$ $\left(\mathrm{H}_{2} \mathrm{O}\right)_{6.01}, Z=2$, calculated on the basis of $42(\mathrm{O}+\mathrm{F})$ a.p.f.u., $\mathrm{H}_{2} \mathrm{O}$ and $\mathrm{OH}$ are calculated from structure refinement $\left(\mathrm{H}_{2} \mathrm{O}=6\right.$ p.f.u.; $\mathrm{F}+\mathrm{OH}=4$ p.f.u.). The crystal structure of nechelyustovite is a combination of a TS (titanium silicate) block and an I (intermediate) block. The TS block consists of $\mathrm{HOH}$ sheets (H-heteropolyhedral, O-octahedral). The TS block exhibits linkage and stereochemistry typical for Group III ( $\mathrm{Ti}=3$ a.p.f.u.) of Ti-disilicate minerals: two $\mathrm{H}$ sheets connect to the $\mathrm{O}$ sheet such that two $\left(\mathrm{Si}_{2} \mathrm{O}_{7}\right)$ groups link to the trans edges of a Ti octahedron of the $\mathrm{O}$ sheet. There are two distinct TS blocks of the same topology, $\mathrm{TS}_{1}$ and $\mathrm{TS}_{2}$, that differ in the cations of the $\mathrm{O}$ sheet, [ $\left.\left(\mathrm{Na}_{1.5} \mathrm{Mn}_{1} \square_{0.5}\right) \mathrm{Ti}\right]$ and $\left[\left(\mathrm{Na}_{2} \mathrm{Mn}_{0.5} \square_{0.5}\right) \mathrm{Ti}\right]$ (4 a.p.f.u.) respectively. The $\mathrm{TS}_{1}$ and $\mathrm{TS}_{2}$ blocks have two different $\mathrm{H}$ sheets, $\mathrm{H}_{1,2}$ and $\mathrm{H}_{3,4}$, where $\left(\mathrm{Si}_{2} \mathrm{O}_{7}\right)$ groups link to [5]- and [6]-coordinated (Ti, $\left.\mathrm{Nb}\right)$ polyhedra respectively. There are three peripheral sites, $A^{P}(1-3)$, occupied mainly by $\mathrm{Ba}$ (less $\mathrm{Sr}$ and $\mathrm{K})$ at 96,86 and $26 \%$ and one peripheral site $A^{P}(4)$ occupied by $\mathrm{Na}$ at $50 \%$. There are two I blocks: the $\mathbf{I}_{1}$ block is a layer of $\mathrm{Ba}$ atoms; the $\mathbf{I}_{2}$ block consists of $\mathrm{H}_{2} \mathrm{O}$ groups and $A^{P}(3)$ atoms. TS blocks alternate with $\mathbf{I}$ blocks or link through hydrogen bonds (as in epistolite). There is a sequence of four TS blocks and three $\mathbf{I}$ blocks per the $c$ cell parameter: $\mathrm{TS}_{2}-\mathbf{I}_{1}-\mathrm{TS}_{1}-\mathbf{I}_{2}-\mathrm{TS}_{1}-\mathbf{I}_{1}-\mathrm{TS}_{2}$.

KEYwords: nechelyustovite, Ti-disilicate minerals, crystal structure, EMP analysis, chemical formula, TS block, Group III.

\section{Introduction}

Nechelyustovite was first described by Khomyakov (1995) under the name M73. The author reported a chemical analysis (see Table 1), an IR spectrum, $D_{\text {meas. }}=3.42 \mathrm{~g} \mathrm{~cm}^{-3}$, a general formula $(\mathrm{Na}, \mathrm{K})_{4}(\mathrm{Ba}, \mathrm{Sr}, \mathrm{Ca}, \mathrm{K})_{2}(\mathrm{Mn}, \mathrm{Fe}) \mathrm{Ti}_{3} \mathrm{Nb}$

* E-mail: camara@crystal.unipv.it

DOI: $10.1180 /$ minmag.2009.073.5.753
$\mathrm{Si}_{6} \mathrm{O}_{25} \mathrm{~F} \cdot n\left(\mathrm{H}_{2} \mathrm{O}\right)$ where $n \sim 8$ and two variants of an idealized formula: (1) $\mathrm{Na}_{4} \mathrm{Ba}_{2} \mathrm{Mn}$ $\mathrm{Ti}_{3} \mathrm{NbSi}_{6} \mathrm{O}_{25} \mathrm{~F} \cdot 8\left(\mathrm{H}_{2} \mathrm{O}\right)$ and (2) $\mathrm{Na}_{3} \mathrm{BaMnTi}_{2}$ $(\mathrm{Nb}, \mathrm{Mn})\left(\mathrm{Si}_{2} \mathrm{O}_{7}\right)_{2}(\mathrm{O}, \mathrm{OH}, \mathrm{F}) \cdot n\left(\mathrm{H}_{2} \mathrm{O}\right)$ where $n \sim 5$. Specimen M73 was mentioned as an example of a heterophyllosilicate with bafertisite-type $\mathrm{HOH}$ layers (Ferraris et al., 2001, 2004; Ferraris and Gula, 2005), the last authors reporting models of two polytypes of the M73 structure which was from work of Nèmeth (2004) and Nèmeth et al. (2004). 
Nechelyustovite was described as a new mineral by Nèmeth et al. (2009). It occurs in a hydrothermally altered pegmatite body in the underground Kirovskii Mine, Mt Kukisvumchorr, the Khibina alkaline massif, Kola peninsula, Russia, as rosettes up to $1-5 \mathrm{~cm}$ in diameter composed of extremely fine $(0.01-0.1 \mathrm{~mm})$ creamy bounded flakes and lamellae associated with natrolite and barytolamprophyllite. Based on selected-area electron diffraction, X-ray powder diffraction and transmission electron microscopy, Nèmeth et al. (2009) reported that nechelyustovite occurs as two polytypes of monoclinic symmetry intergrown at the submicroscopic scale (also intergrown at microscopic scale with natrolite and barytolamprophyllite): nechelyustovite- $1 M$, space group $P 2 / m, a 5.37 \AA, b 7.00 \AA, c 24.05$ $\AA, \beta 91.1^{\circ}, Z=2$, and nechelyustovite- $2 M$, space group $A 2 / m, a 5.38 \AA, b 7.04 \AA$, c $48.10 \AA$, $\beta$ $91.1^{\circ}, Z=4$. They presented a chemical analysis (see Table 1) and the crystal-chemical formula $\left(\mathrm{Ba}_{0.75} \mathrm{Sr}_{0.25} \mathrm{~K}_{0.17} \mathrm{Ce}_{0.02} \mathrm{Ca}_{0.01} \square 0.80\right)_{\Sigma 2}$ $\left\{\left(\mathrm{Na}_{2.20} \mathrm{Ti}_{0.94} \mathrm{Mn}_{0.62} \mathrm{Ca}_{0.20} \mathrm{Fe}_{0.04}\right)_{\Sigma 4}\right.$ $\left.\left(\mathrm{Ti}_{1.33} \mathrm{Nb}_{0.67}\right)_{\Sigma 2} \mathrm{O}_{2}\left(\mathrm{Si}_{2} \mathrm{O}_{7}\right)_{2}\left(\mathrm{O}_{1.30} \mathrm{H}_{2} \mathrm{O}_{0.70}\right)_{\Sigma 2}\right\}$ -4.325( $\left.\mathrm{H}_{2} \mathrm{O}\right), D_{\text {calc. }} 3.22 \mathrm{~g} \mathrm{~cm}^{-3}$. They gave a simplified formula of nechelyustovite as follows $(\mathrm{Ba}, \mathrm{Sr}, \mathrm{K}, \square)_{2}\left\{(\mathrm{Na}, \mathrm{Ti}, \mathrm{Mn})_{4}(\mathrm{Ti}, \mathrm{Nb})_{2} \mathrm{O}_{2}\right.$ $\left.\left(\mathrm{Si}_{2} \mathrm{O}_{7}\right)_{2}\left(\mathrm{O}, \mathrm{H}_{2} \mathrm{O}, \mathrm{F}\right)\right\} \cdot 4.5 \mathrm{H}_{2} \mathrm{O}$. Nèmeth et al.

TABLE 1. Chemical composition (wt.\%) and unit formula (a.p.f.u.) for nechelyustovite.

\begin{tabular}{|c|c|c|c|c|c|}
\hline & $\begin{array}{c}\text { Khomyakov } \\
\text { (1995) }\end{array}$ & $\begin{array}{c}{ }^{1} \text { Nèmeth et al. } \\
\text { (2009) }\end{array}$ & ${ }^{2}$ This work & & \\
\hline Oxide & & & Wt.\% & $\begin{array}{l}\text { Cations } \\
\mathrm{Si}\end{array}$ & $\begin{array}{l}\text { a.p.f.u. } \\
8.03\end{array}$ \\
\hline $\mathrm{Nb}_{2} \mathrm{O}_{5}$ & 10.14 & 10.14 & 11.43 & & \\
\hline $\mathrm{Ta}_{2} \mathrm{O}_{5}$ & n.a. & n.a. & n.d. & $\mathrm{Mn}^{2+}$ & 1.11 \\
\hline $\mathrm{SiO}_{2}$ & 27.60 & 27.33 & 28.94 & $\mathrm{Ca}$ & 0.46 \\
\hline $\mathrm{TiO}_{2}$ & 18.30 & 20.59 & 19.85 & $\mathrm{Na}$ & 4.21 \\
\hline $\mathrm{ZrO}_{2}$ & n.d. & n.a. & n.d. & $\Sigma\left[6 \mathrm{M}^{\mathrm{O}}+\mathrm{A}^{P}\right]^{3}$ & 5.78 \\
\hline $\mathrm{Al}_{2} \mathrm{O}_{3}$ & n.d. & n.d. & 0.11 & & \\
\hline $\mathrm{Ce}_{2} \mathrm{O}_{3}$ & n.d. & 0.35 & n.d. & $\mathrm{Sr}$ & 0.5 \\
\hline $\mathrm{Fe}_{2} \mathrm{O}_{3}$ & 0.00 & 0 & 0.27 & $\mathrm{Ba}$ & 1.28 \\
\hline $\mathrm{FeO}$ & 0.27 & 0.35 & 0 & $\mathrm{~K}$ & 0.3 \\
\hline $\mathrm{MnO}$ & 4.97 & 4.98 & 6.12 & $\Sigma 3 \mathrm{~A}^{P 4}$ & 2.08 \\
\hline $\mathrm{MgO}$ & n.d. & n.a. & n.d. & & \\
\hline $\mathrm{CaO}$ & 1.30 & 1.34 & 1.55 & $\mathrm{Nb}$ & 1.43 \\
\hline $\mathrm{SrO}$ & 2.75 & 2.91 & 3.11 & $\mathrm{Ti}$ & 4.14 \\
\hline $\mathrm{BaO}$ & 12.39 & 13.05 & 11.80 & $\mathrm{Al}$ & 0.04 \\
\hline $\mathrm{Na}_{2} \mathrm{O}$ & 9.44 & 7.76 & 7.85 & $\mathrm{Fe}^{3+}$ & 0.06 \\
\hline $\mathrm{K}_{2} \mathrm{O}$ & 1.12 & 0.92 & 0.84 & $\mathrm{Mn}^{2+}$ & 0.33 \\
\hline $\mathrm{F}$ & 1.34 & n.d. & 1.21 & $\Sigma\left(4 \mathrm{M}^{\mathrm{H}}+2 \mathrm{M}^{\mathrm{O}}\right)$ & 6.00 \\
\hline $\mathrm{H}_{2} \mathrm{O}$ & 10.94 & $10.30^{5}$ & $8.08^{6}$ & & \\
\hline sub total & 100.56 & 100.00 & 101.16 & Anions & \\
\hline less $\mathrm{O} \equiv \mathrm{F}_{2}$ & 0.56 & 0 & 0.51 & $\mathrm{~F}$ & 1.06 \\
\hline \multirow[t]{2}{*}{ Total } & 100.00 & 100.00 & 100.65 & $\begin{array}{l}\mathrm{OH} \\
\Sigma \mathrm{X}_{\mathrm{A}}^{\mathrm{O}}\end{array}$ & $\begin{array}{l}2.94 \\
4.00\end{array}$ \\
\hline & & & & $\mathrm{H}_{2} \mathrm{O}$ & 6.01 \\
\hline
\end{tabular}

n.d.: not detected; n.a.: not analysed.

${ }^{1}$ chemical data were obtained from a mixture of nechelyustovite and natrolite and the natrolite contribution of the ideal composition $\mathrm{Na}_{2} \mathrm{Al}_{2} \mathrm{Si}_{3} \mathrm{O}_{10}\left(\mathrm{H}_{2} \mathrm{O}\right)_{2}$ was later subtracted on the assumption that all $\mathrm{Al}$ belongs to the natrolite component.

2 electron microprobe analysis from a single crystal used for structure solution and refinement and two other crystals.

${ }^{3} \mathrm{~A}^{P}=\mathrm{A}^{P}(4)$

${ }_{5}^{4} 3 \mathrm{~A}^{P}=\mathrm{A}^{P}(1)+\mathrm{A}^{P}(2)+\mathrm{A}^{P}(3)$

5 calculated by difference.

${ }^{6}$ calculated from structure refinement on the basis of 42 anions: $\mathrm{F}+\mathrm{OH}=4$ a.p.f.u., $\mathrm{H}_{2} \mathrm{O}=6$ a.p.f.u. 
(2009) commented that (1) the presence of nechelyustovite in the very poor X-ray powder diffraction pattern with broad peaks was $<<10 \%$, the rest being major natrolite and minor barytolamprophyllite, and (2) electron microprobe analysis was done on nechelyustovite intergrown with natrolite in the approximate ratio $1: 1$ and that the $\mathrm{H}_{2} \mathrm{O}$ content was assigned as the difference from $100 \%$. Although Nèmeth et al. (2009) did not provide any numerical description of a structure model for either polytype, they gave

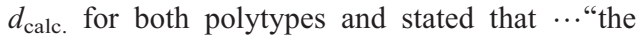
choice of seven strongest reflections was based on $\mathrm{I}_{\text {calc }}$ of the $P 2 / \mathrm{m}$ polytype".. . They concluded their paper with statement that ..."the crystal structure of nechelyustovite is based on bafertisite-type $\mathrm{HOH}$ layers" $\cdots$, in accord with Ferraris and Gula (2005), but seemed unaware of the incongruity of their model in light of the work of Sokolova (2006).

Sokolova (2006) considered structural hierarchy and stereochemistry for 24 Ti-disilicate minerals containing the TS (Ti-silicate) block, a trioctahedral central $(\mathrm{O})$ sheet and two adjacent $(\mathrm{H})$ sheets containing different polyhedra including $\left(\mathrm{Si}_{2} \mathrm{O}_{7}\right)$ groups. Structures with the TS block have a characteristic two-dimensional minimal cell in the plane of the O sheet, with $t_{1} \approx 5.5$ and $t_{2} \approx 7.1 \AA$, $\mathbf{t}_{\mathbf{1}} \wedge \mathbf{t}_{\mathbf{2}} \sim 90^{\circ}$. Sokolova (2006) established the relation between structure topology and chemical composition for those minerals and divided them into four groups, characterized by different topology and stereochemistry of the TS block. The topology and stereochemistry of the TS block is strongly related to the stereochemistry of Ti. In Groups I, II III and IV, Ti equals 1, 2, 3 and 4 a.p.f.u. (atoms per formula unit) respectively. Each group of structures has a different linkage of $\mathrm{H}$ and $\mathrm{O}$ sheets in the TS block, and a different arrangement of $\mathrm{Ti}(=\mathrm{Ti}+\mathrm{Nb})$ polyhedra. In a structure, the TS block can alternate with another block, an intermediate (I) block, so called as it is intercalated between two TS blocks. Sokolova (2006) described the general structural principles for TS-block minerals in a quantitative way, and the relation between structure topology and chemical composition was established for those minerals. These principles allow prediction of structural arrangements and possible chemical compositions, and testing whether or not all aspects of the structure and chemical formula of a mineral are correct.

We question the validity of the structure model of nechelyustovite polytypes reported by Ferraris and Gula (2005) (Fig. 1). In their model, the TS block has linkage 2, as in Group II of Sokolova (2006) where Ti equals 2 a.p.f.u. and $\left(\mathrm{Si}_{2} \mathrm{O}_{7}\right)$ groups link to two $\mathrm{M}^{\mathrm{O}}$ octahedra of the $\mathrm{O}$ sheet adjacent along $\mathbf{t}_{2}$. Ferraris and Gula (2005) stated that both polytypes show topology of the $\mathrm{HOH}$ layer block characteristic for bafertisite. Bafertisite belongs to Group II ( $\mathrm{Ti}=2$ a.p.f.u.) in the terminology of Sokolova (2006). In nechelyustovite, Ti equals 3 a.p.f.u. Hence, nechelyustovite belongs to Group III and the TS block must exhibit linkage 1 and the stereochemistry of Group III: Ti occurs in both the $\mathrm{H}$ and $\mathrm{O}$ sheets, and two $\left(\mathrm{Si}_{2} \mathrm{O}_{7}\right)$ groups link to trans edges of a $\mathrm{Ti}$ octahedron in the $\mathrm{O}$ sheet.

This work is a continuation of our interest in Ti-disilicates and it follows revision of the crystal structure and chemical formula of delindeite (Sokolova and Cámara, 2007), determination of the crystal structure of bornemanite (Cámara and Sokolova, 2007), revision of the chemical formula and crystal chemistry of barytolamprophyllite (Sokolova and Cámara, 2008a), mosandrite from the type locality (Sokolova and Cámara, 2008b), structure work on an orthorhombic polytype of nabalamprophyllite (Sokolova and Hawthorne, $2008 a$ ), nacareniobsite-(Ce) (Sokolova and Hawthorne, 2008b), lomonosovite and murmanite (Cámara et al., 2008) and jinshajiangite (Sokolova et al., 2009). The sample of nechelyustovite from Mt Kukisvumchorr, the Khibiny alkaline massif, Kola Peninsula, Russia, was kindly provided by Adriana and Renato Pagano, Milan, Italy, from their mineral collection (Collezione Mineralogica, sample \#10161). This sample of nechelyustovite came from A.P. Khomyakov, was described in Khomyakov (1995), and a holotype sample of nechelyustovite deposited at the Fersman Mineralogical Museum is a part of this sample (Khomyakov, pers. comm.). This paper presents an average crystal structure of nechelyustovite, revision of its chemical formula and discusses its relation to other group-III TS-block minerals.

\section{Experimental details}

\section{Sample description}

Crystal selection was very difficult due to the intimate admixture of nechelyustovite and natrolite. Nechelyustovite crystals are wavy and bent, and they separate into very thin flakes. Most flakes that show optical extinction diffract either as a powder or have sharp round diffraction spots 

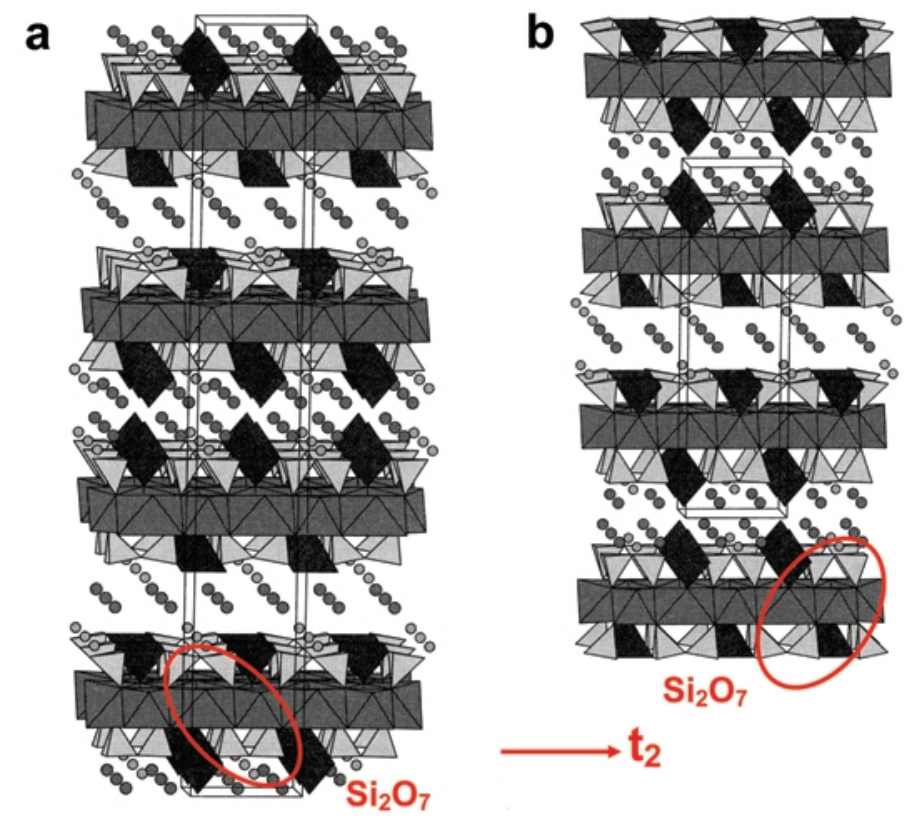

FIG. 1. View along [100] of the crystal structure of two M73 polytypes. Smaller and larger circles represent cations and $\mathrm{H}_{2} \mathrm{O}$ molecules, respectively. Note that the $\mathrm{X}$ cation shows either octahedral or pyramidal coordination (dark grey polyhedra). The figure and figure caption cited above are after Ferraris and Gula (2005), fig. 7, p.80. Our additions are in red: ovals show two $\mathrm{Si}_{2} \mathrm{O}_{7}$ groups of two $\mathrm{H}$ sheets in one TS block; along $\mathbf{t}_{2}$ translation, $\mathrm{Si}_{2} \mathrm{O}_{7}$ link to two adjacent octahedra in the O sheet [linkage 2 as in Group II of Sokolova (2006)].

shape on (001) but almost continuous streaks along [001]. Some crystals have discrete diffraction profiles along [001] and can be indexed as nechelyustovite. However, some degree of mosaicity is always present. The single crystal of nechelyustovite that was used in this work is a transparent creamy plate with dimensions $0.120 \mathrm{~mm} \times 0.055 \mathrm{~mm} \times 0.015 \mathrm{~mm}$. The crystal is of fair quality. Three other poorer-quality crystals from the same sample were used for electron microprobe analysis (Fig. 2).

\section{Electron microprobe analysis}

Three crystals of nechelyustovite were analysed with a Cameca SX100 electron microprobe operating in wavelength-dispersive mode with an accelerating voltage of $15 \mathrm{kV}$, a probe current of $20 \mathrm{nA}$, a final beam diameter of $10 \mu \mathrm{m}$ and count times on peak and background of 20 and $30 \mathrm{~s}$ respectively for major and minor elements $(<1$ wt.\%). The following standards and X-ray lines used for the analysis were as follows: fluorite for $\mathrm{F}-K \alpha$; albite for $\mathrm{Na}-K \alpha$; forsterite for $\mathrm{Mg}-K \alpha$; andalusite for $\mathrm{Al}-K \alpha$; diopside for $\mathrm{Si}-K \alpha$ and $\mathrm{Ca}-K \alpha$; apatite for $\mathrm{P}-K \alpha$; orthoclase for $\mathrm{K}-K \alpha$; titanite for Ti- $K \alpha$; almandine for Mn- $K \alpha$; fayalite for $\mathrm{Fe}-K \alpha ; \mathrm{SrTiO}_{3}$ for $\mathrm{Sr}-L \alpha ; \mathrm{ZrO}_{2}$ for $\mathrm{Zr}-L \mathrm{a}$; $\mathrm{Ba}_{2} \mathrm{NaNb}_{5} \mathrm{O}_{15}$ for $\mathrm{Nb}-L \alpha$ and $\mathrm{Ba}-L \alpha ; \mathrm{MnTa}_{2} \mathrm{O}_{6}$ for Ta- $L \alpha$. Data were reduced using the PAP

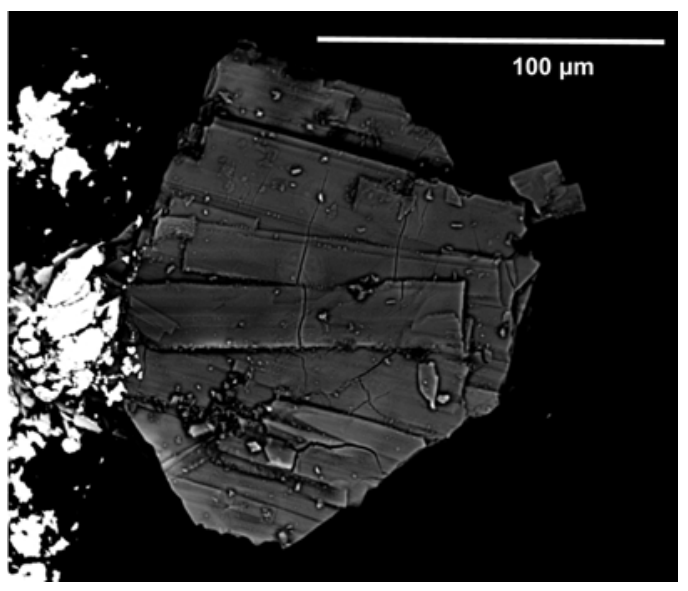

FIG. 2. BSE image of nechelyustovite grain 2 (one of three used for electron microprobe analysis). 
procedure of Pouchou and Pichoir (1985). The chemical composition of nechelyustovite is given in Table 1 and is the mean of 14 determinations; it is in good agreement with the chemical analyses of Khomyakov (1995) and Nèmeth et al. (2009). The empirical formula is $\left(\mathrm{Na}_{4.21} \mathrm{Mn}_{1.11}^{2+} \mathrm{Ca}_{0.46}\right.$ $\left.\square_{1.22}\right)_{\Sigma 7.00}\left(\mathrm{Ba}_{1.28} \mathrm{Sr}_{0.50} \mathrm{~K}_{0.30} \square_{0.92}\right)_{\Sigma 3.00}\left(\mathrm{Ti}_{4.14}\right.$ $\left.\mathrm{Nb}_{1.43} \mathrm{Mn}_{0.33}^{2+} \mathrm{Fe}_{0.06}^{3+} \mathrm{Al}_{0.04}\right)_{\Sigma 6}\left(\mathrm{Si}_{8.03} \mathrm{O}_{28}\right) \mathrm{O}_{3.99}$ $\left[(\mathrm{OH})_{2.94} \mathrm{~F}_{1.06}\right]_{\Sigma 4}\left(\mathrm{H}_{2} \mathrm{O}\right)_{6.01}, \mathrm{Z}=2$, calculated on the basis of $42\left(\mathrm{O}+\right.$ F) a.p.f.u.; $\mathrm{H}_{2} \mathrm{O}$ and $\mathrm{OH}$ are calculated from the structure refinement $\left(\mathrm{H}_{2} \mathrm{O}=\right.$ 6 p.f.u.; $\mathrm{F}+\mathrm{OH}=4$ a.p.f.u.).

\section{Data collection and crystal structure refinement}

A single crystal of nechelyustovite was mounted on a Bruker AXS SMART APEX diffractometer with a CCD detector and Mo- $K \alpha$ radiation. The intensities of reflections were collected to $54.29^{\circ} 2 \theta$ using $30 \mathrm{~s}$ per $0.2^{\circ}$ frame, and an empirical absorption correction (SADABS,
Sheldrick, 1998) was applied. The refined unitcell parameters for the triclinic cell (Table 2) were obtained from 2292 reflections with $I>10 \sigma$. The crystal structure of nechelyustovite was solved by direct methods with the Bruker SHELXTL Version 5.1 system of programs (Sheldrick, 1997) and refined in space group $P \overline{1}$ to $R_{1}=19.70 \%$ and a $\mathrm{GoF}=1.141$ and in space group $P 1$ to $R_{1}=11.85 \%$ and a GoF of 1.122 . The refinement of the structure was based on 4414 intensities of unique observed reflections $\left(F_{\mathrm{o}}>\right.$ $4 \sigma F)$ with $-6<h<6,-9<k<9,-60<l<60$. Scattering curves for neutral atoms were taken from the International Tables for Crystallography (1992). Site occupancies for the (Ti,Nb) sites were refined with the scattering curves of $\mathrm{Nb}$; for the O-sheet sites occupied by the alkaline cations, with the scattering curves of $\mathrm{Na}, \mathrm{Ca}$ and $\mathrm{Mn}$; for the I-block sites, with the scattering curves of $\mathrm{Ba}$, $\mathrm{K}$ and $\mathrm{Na}$. In spite of a lower value of $R_{1}$ in space group $P 1$ (if compared to space group $P \overline{1}$ ), the $P 1$

TABLE 2. Miscellaneous refinement data for nechelyustovite.

\begin{tabular}{|c|c|}
\hline$a(\AA)$ & $5.447(1)$ \\
\hline$b$ & $7.157(1)$ \\
\hline$c$ & $47.259(9)$ \\
\hline$\alpha\left({ }^{\circ}\right)$ & $97.759(4)$ \\
\hline$\beta$ & $92.136(4)$ \\
\hline$\gamma$ & $89.978(4)$ \\
\hline$V\left(\AA^{3}\right)$ & $1831.7(4)$ \\
\hline Space group & $P \overline{1}$ \\
\hline Z & 2 \\
\hline Absorption coefficient $\left(\mathrm{mm}^{-1}\right)$ & 4.41 \\
\hline$F(000)$ & 1608.2 \\
\hline$D_{\text {calc. }}\left(\mathrm{g} \mathrm{cm}^{-3}\right)$ & 3.041 \\
\hline Crystal size $(\mathrm{mm})$ & $0.12 \times 0.055 \times 0.015$ \\
\hline Radiation/filter & Mo- $K \alpha /$ graphite \\
\hline $2 \theta$-range for data collection $\left({ }^{\circ}\right)$ & $50.05^{*}$ \\
\hline$R$ (int) $(\%)$ & 8.00 \\
\hline Reflections collected & 13959 \\
\hline Independent reflections & 6342 \\
\hline$F_{\mathrm{o}}>15 \sigma F$ & 1745 \\
\hline Refinement method & $\begin{array}{l}\text { Full-matrix least squares on } F^{2}, \\
\text { fixed weights proportional to } 1 / \sigma F_{\mathrm{o}}^{2}\end{array}$ \\
\hline No. of refined parameters & 349 \\
\hline Goodness of Fit on $F^{2}$ & 1.168 \\
\hline $\begin{array}{l}\text { Final } R \text { (obs.) } \\
{\left[F_{\mathrm{o}}>15 \sigma F\right]}\end{array}$ & $R_{1}=13.94$ \\
\hline$R$ indices (all data) $(\%)$ & $\begin{array}{l}R_{1}=27.80 \\
w R_{2}=47.76 \\
\mathrm{GoF}=1.168\end{array}$ \\
\hline
\end{tabular}

* used for the structure refinement, see discussion in the text. 
structure model was characterized by high correlation coefficients between pairs of variables related by a pseudo centre of symmetry, the assigned site occupancies for half the alkali-cation sites in the $\mathrm{O}$ sheet were not supported by corresponding mean bond lengths, and $\mathrm{Si}-\mathrm{O}$ bond lengths were either too short or too long. The $P \overline{1}$ model did not have these problems. We chose the space group $P \overline{1}$ for further refinement. We were aware that the quality of the crystal would allow us to get only an average structure model. For further refinement, we used a set of 1745 unique observed reflections $\left(F_{\mathrm{o}}>15 \sigma F\right)$ with $-6<h<6,-8<k<8,-56<l<56,2 \theta$ $\leqslant 50.05^{\circ}$. Although our crystal was the best that we could find it was not of a good quality. We cut our data so that we have at least 5 strong reflections per a refined parameter. Because of poor experimental data, we provide, later in the text, a detailed discussion proving that, crystalchemically, our model is correct. Site occupancies for the $M^{\mathrm{H}}(1-4), M^{\mathrm{O}}(1,2) ; \mathrm{M}^{\mathrm{O}}(3,4), M^{\mathrm{O}}(5-8)$; $A^{P}(1-3)$ and $A^{P}(4)$ sites were refined with the scattering curves of $\mathrm{Nb} ; \mathrm{Ca} ; \mathrm{Ba}$ and $\mathrm{Na}$, respectively. After refinement of cation-site occupancies, they were adjusted in accord with the chemical analysis and mean bond lengths, and fixed. At the last stages of the refinement, 13 peaks with magnitudes from 3 to $6-e$ were found in the difference-Fourier map, most of these peaks occurring in the vicinity of the Ba-dominant $A^{P}(1-3)$ sites. Therefore occupancies for peaks $1-13$ were refined with the scattering curve of $\mathrm{Ba}$ (the heaviest scatter in the structure) at the fixed $U_{\text {iso }}=0.01 \AA^{2}$. Refined occupancies of these subsidiary sites vary from 2 to $10 \%$. The 13 out of the $32 \mathrm{Si}-\mathrm{O}$ distances were either too short $(\sim 1.54 \AA)$ or too long $(\sim 1.73 \AA)$, a relatively

TABLE 3. Atomic coordinates and isotropic temperature parameters $\left(\AA^{2}\right)$.

\begin{tabular}{lclccc}
\hline Atom & Site occupancy & \multicolumn{1}{c}{$x$} & $y$ & $z$ & $U_{\text {iso }}{ }^{*}$ \\
\hline $\mathrm{M}^{\mathrm{O}}(1)$ & 1 & $0.808(3)$ & $0.888(2)$ & $0.3336(4)$ & $0.022(5)$ \\
$\mathrm{M}^{\mathrm{O}}(2)$ & 1 & $0.915(4)$ & $0.253(3)$ & $0.1266(5)$ & $0.025(6)$ \\
$\mathrm{M}^{\mathrm{O}}(3)$ & 0.70 & $0.803(8)$ & $0.392(7)$ & $0.3399(12)$ & $0.005(11)$ \\
$\mathrm{M}^{\mathrm{O}}(4)$ & 0.70 & $0.932(8)$ & $0.757(6)$ & $0.1240(10)$ & $0.007(11)$ \\
$\mathrm{M}^{\mathrm{O}}(5)$ & 0.92 & $0.300(4)$ & $0.130(3)$ & $0.3359(5)$ & $0.012(5)$ \\
$\mathrm{M}^{\mathrm{O}}(6)$ & 0.78 & $0.304(4)$ & $0.645(3)$ & $0.3360(5)$ & $0.010(5)$ \\
$\mathrm{M}^{\mathrm{O}}(7)$ & 0.93 & $0.427(5)$ & $0.005(4)$ & $0.1246(7)$ & $0.021(8)$ \\
$\mathrm{M}^{\mathrm{O}}(8)$ & 0.95 & $0.430(5)$ & $0.496(4)$ & $0.1243(7)$ & $0.020(8)$ \\
$\mathrm{M}^{\mathrm{H}}(1)$ & 1 & $0.270(2)$ & $0.7136(15)$ & $0.0600(2)$ & $0.022(3)$ \\
$\mathrm{M}^{\mathrm{H}}(2)$ & 1 & $0.468(3)$ & $0.4356(19)$ & $0.4007(3)$ & $0.025(4)$ \\
$\mathrm{M}^{\mathrm{H}}(3)$ & 1 & $0.126(4)$ & $0.343(3)$ & $0.2715(5)$ & $0.024(6)$ \\
$\mathrm{M}^{\mathrm{H}}(4)$ & 1 & $0.597(3)$ & $0.790(2)$ & $0.1868(4)$ & $0.019(4)$ \\
$\mathrm{Si}(1)$ & 1 & $0.629(3)$ & $0.635(2)$ & $0.2757(3)$ & $0.007(6)$ \\
$\mathrm{Si}(2)$ & 1 & $0.631(2)$ & $0.083(3)$ & $0.2766(3)$ & $0.013(6)$ \\
$\mathrm{Si}(3)$ & 1 & $0.967(3)$ & $0.142(3)$ & $0.3930(5)$ & $0.011(6)$ \\
$\mathrm{Si}(4)$ & 1 & $0.965(3)$ & $0.712(2)$ & $0.3935(5)$ & $0.018(7)$ \\
$\mathrm{Si}(5)$ & 1 & $0.089(4)$ & $0.507(3)$ & $0.1838(5)$ & $0.002(5)$ \\
$\mathrm{Si}(6)$ & 1 & $0.098(4)$ & $0.084(3)$ & $0.1839(5)$ & $0.000(5)$ \\
$\mathrm{Si}(7)$ & 1 & $0.766(3)$ & $0.4228(4)$ & $0.0673(2)$ & $0.014(6)$ \\
$\mathrm{Si}(8)$ & 1 & $0.775(4)$ & $0.008(4)$ & $0.06727(6)$ & $0.021(7)$ \\
$\mathrm{A}^{P}(1)$ & 0.96 & $0.1172(13)$ & $0.8267(10)$ & $0.2436(2)$ & $0.011(2)$ \\
$\mathrm{A}^{P}(2)$ & 0.84 & $0.6115(14)$ & $0.3069(11)$ & $0.2149(3)$ & $0.005(2)$ \\
$\mathrm{A}^{P}(3)$ & 0.26 & $0.477(5)$ & $0.954(3)$ & $0.4318(6)$ & $0.012(6)$ \\
$\mathrm{A}^{P}(4)$ & 0.5 & $0.273(12)$ & $0.218(7)$ & $0.0505(5)$ & $0.013(15)$ \\
$\mathrm{O}(1)$ & 1 & $0.628(9)$ & $0.656(7)$ & $0.3093(3)$ & $0.000(12)$ \\
$\mathrm{O}(2)$ & 1 & $0.383(9)$ & $0.521(7)$ & $0.2629(11)$ & $0.000(12)$ \\
$\mathrm{O}(3)$ & 1 & $0.875(4)$ & $0.537(6)$ & $0.2656(10)$ & $0.001(12)$ \\
$\mathrm{O}(4)$ & 1 & $0.593(10)$ & $0.849(3)$ & $0.2646(10)$ & $0.009(14)$ \\
$\mathrm{O}(5)$ & 1 & $0.381(5)$ & $0.151(7)$ & $0.2620(11)$ & $0.017(16)$ \\
$\mathrm{O}(6)$ & 1 & $0.611(9)$ & $0.085(7)$ & $0.3106(4)$ & $0.001(12)$ \\
$\mathrm{O}(7)$ & 1 & $0.882(5)$ & $0.139(8)$ & $0.2625(11)$ & $0.030(18)$ \\
& & & & &
\end{tabular}


TABLE 3 (contd.)

\begin{tabular}{|c|c|c|c|c|c|}
\hline Atom & Site occupancy & $x$ & $y$ & $z$ & $U_{\text {iso }} *$ \\
\hline $\mathrm{O}(8)$ & 1 & $0.716(5)$ & $0.229(8)$ & $0.4038(13)$ & $0.027(18)$ \\
\hline $\mathrm{O}(9)$ & 1 & $0.23922(0)$ & $0.19603(0)$ & $0.40394(0)$ & $0.023(16)$ \\
\hline $\mathrm{O}(10)$ & 1 & $0.970(10)$ & $0.106(7)$ & $0.3584(12)$ & $0.005(13)$ \\
\hline $\mathrm{O}(11)$ & 1 & $0.993(13)$ & $0.943(3)$ & $0.4054(14)$ & $0.04(2)$ \\
\hline $\mathrm{O}(12)$ & 1 & $0.737(7)$ & $0.619(8)$ & $0.4062(14)$ & $0.05(2)$ \\
\hline $\mathrm{O}(13)$ & 1 & $0.228(10)$ & $0.632(7)$ & $0.4052(12)$ & $0.006(13)$ \\
\hline $\mathrm{O}(14)$ & 1 & $0.972(11)$ & $0.700(8)$ & $0.3578(13)$ & $0.019(16)$ \\
\hline $\mathrm{O}(15)$ & 1 & $0.070(12)$ & $0.463(9)$ & $0.1494(14)$ & $0.019(16)$ \\
\hline $\mathrm{O}(16)$ & 1 & $0.872(9)$ & $0.623(7)$ & $0.1995(12)$ & $0.000(12)$ \\
\hline $\mathrm{O}(18)$ & 1 & $0.080(9)$ & $0.304(7)$ & $0.1987(11)$ & $0.000(12)$ \\
\hline $\mathrm{O}(17)$ & 1 & $0.352(12)$ & $0.592(9)$ & $0.1969(15)$ & $0.025(18)$ \\
\hline $\mathrm{O}(19)$ & 1 & $0.341(9)$ & $-0.018(7)$ & $0.1973(12)$ & $0.000(12)$ \\
\hline $\mathrm{O}(20)$ & 1 & $0.858(9)$ & $-0.014(7)$ & $0.1956(11)$ & $0.000(12)$ \\
\hline $\mathrm{O}(21)$ & 1 & $0.073(9)$ & $0.068(7)$ & $0.1502(11)$ & $0.000(12)$ \\
\hline $\mathrm{O}(22)$ & 1 & $0.013(9)$ & $0.509(7)$ & $0.0544(12)$ & $0.007(13)$ \\
\hline $\mathrm{O}(23)$ & 1 & $0.517(5)$ & $0.516(9)$ & $0.0564(16)$ & $0.07(3)$ \\
\hline $\mathrm{O}(24)$ & 1 & $0.802(11)$ & $0.451(9)$ & $0.1012(3)$ & $0.017(16)$ \\
\hline $\mathrm{O}(25)$ & 1 & $0.785(9)$ & $0.2077(13)$ & $0.0525(6)$ & $0.006(13)$ \\
\hline $\mathrm{O}(26)$ & 1 & $0.806(10)$ & $0.029(10)$ & $0.10082(10)$ & $0.030(19)$ \\
\hline $\mathrm{O}(27)$ & 1 & $-0.010(12)$ & $0.892(9)$ & $0.0505(15)$ & $0.032(18)$ \\
\hline $\mathrm{O}(28)$ & 1 & $0.522(10)$ & $0.883(8)$ & $0.0551(13)$ & $0.012(14)$ \\
\hline $\mathrm{X}_{\mathrm{M}}^{\mathrm{O}}(1) \mathrm{O}$ & 1 & $0.286(10)$ & $0.726(8)$ & $0.0970(13)$ & $0.012(14)$ \\
\hline $\mathrm{X}_{\mathrm{M}}^{\mathrm{O}}(2) \mathrm{O}$ & 1 & $0.464(14)$ & $0.395(10)$ & $0.3633(16)$ & $0.03(2)$ \\
\hline$X_{M}^{O}(3) O$ & 1 & $0.148(10)$ & $0.363(7)$ & $0.3069(13)$ & $0.003(13)$ \\
\hline $\mathrm{X}_{\mathrm{M}}^{\mathrm{O}}(4) \mathrm{O}$ & 1 & $0.583(12)$ & $0.763(9)$ & $0.1502(14)$ & $0.018(16)$ \\
\hline $\mathrm{X}_{\mathrm{A}}^{\mathrm{O}}(1) \mathrm{OH}, \mathrm{F}$ & 1 & $0.519(13)$ & $0.908(10)$ & $0.3589(16)$ & $0.029(19)$ \\
\hline $\mathrm{X}_{\mathrm{A}}^{\mathrm{O}}(2) \mathrm{OH}, \mathrm{F}$ & 1 & $0.083(10)$ & $0.874(7)$ & $0.3091(12)$ & $0.002(12)$ \\
\hline $\mathrm{X}_{\mathrm{A}}^{\mathrm{O}}(3) \mathrm{OH}, \mathrm{F}$ & 1 & $0.638(15)$ & $0.263(11)$ & $0.1478(17)$ & $0.04(2)$ \\
\hline $\mathrm{X}_{\mathrm{A}}^{\mathrm{O}}(4) \mathrm{OH}, \mathrm{F}$ & 1 & $0.227(11)$ & $0.242(8)$ & $0.1037(13)$ & $0.012(15)$ \\
\hline $\mathrm{X}_{\mathrm{M}}^{P}(1) \mathrm{H}_{2} \mathrm{O}$ & 1 & $0.744(14)$ & $0.313(10)$ & $-0.0101(3)$ & $0.04(2)$ \\
\hline $\mathrm{X}_{\mathrm{M}}^{P}(2) \mathrm{H}_{2} \mathrm{O}$ & 1 & $0.488(14)$ & $0.472(10)$ & $0.4507(3)$ & $0.03(2)$ \\
\hline $\mathrm{X}_{\mathrm{A}}^{P}(1) \mathrm{H}_{2} \mathrm{O}$ & 1 & $0.262(13)$ & $0.263(9)$ & $0.0042(6)$ & $0.043(18)$ \\
\hline $\mathrm{X}_{\mathrm{A}}^{P}(2) \mathrm{H}_{2} \mathrm{O}$ & 0.25 & $0.24177(0)$ & $0.17071(0)$ & $0.47177(0)$ & $0.03(6)$ \\
\hline $\mathrm{X}_{\mathrm{A}}^{P}(3) \mathrm{H}_{2} \mathrm{O}$ & 0.25 & $0.69676(0)$ & $0.75637(0)$ & $0.47072(0)$ & $0.06(6)$ \\
\hline W(1) $\mathrm{H}_{2} \mathrm{O}$ & 1 & $-0.008(13)$ & $0.524(10)$ & $0.4544(16)$ & $0.055(19)$ \\
\hline $\mathrm{W}(2) \mathrm{H}_{2} \mathrm{O}$ & 1 & $0.896(12)$ & $0.328(9)$ & $0.4976(15)$ & $0.094(18)$ \\
\hline $\mathrm{W}(3) \mathrm{H}_{2} \mathrm{O}$ & 0.5 & $0.17247(0)$ & $0.00281(0)$ & $0.49839(0)$ & $0.01(3)$ \\
\hline \multicolumn{6}{|c|}{ Subsidiary peaks** } \\
\hline 1 & 0.09 & $0.232(11)$ & $0.308(8)$ & $0.9828(14)$ & 0.01 \\
\hline 2 & 0.07 & $0.620(16)$ & $0.333(12)$ & $0.230(2)$ & 0.01 \\
\hline 3 & 0.06 & $0.610(18)$ & $0.262(13)$ & $0.198(3)$ & 0.01 \\
\hline 4 & 0.10 & $0.481(11)$ & $0.958(8)$ & $0.4131(15)$ & 0.01 \\
\hline 5 & 0.07 & $0.790(13)$ & $0.374(11)$ & $0.324(2)$ & 0.01 \\
\hline 6 & 0.06 & $0.744(17)$ & $0.458(15)$ & $0.332(2)$ & 0.01 \\
\hline 7 & 0.06 & $0.068(15)$ & $0.580(12)$ & $0.139(2)$ & 0.01 \\
\hline 8 & 0.02 & $0.20(4)$ & $0.46(3)$ & $0.355(5)$ & 0.01 \\
\hline 9 & 0.04 & $0.19(2)$ & $0.906(17)$ & $0.326(3)$ & 0.01 \\
\hline 10 & 0.05 & $0.150(17)$ & $0.924(13)$ & $0.287(2)$ & 0.01 \\
\hline 11 & 0.08 & $0.147(16)$ & $0.360(12)$ & $0.284(2)$ & 0.01 \\
\hline 12 & 0.05 & $0.14(2)$ & $0.834(15)$ & $0.259(3)$ & 0.01 \\
\hline 13 & 0.05 & $0.49(2)$ & $0.442(16)$ & $0.413(3)$ & 0.01 \\
\hline
\end{tabular}

* $U_{\text {eq }}$ for $\mathrm{M}^{\mathrm{O}}(1,2,7,8), \mathrm{M}^{\mathrm{H}}(1-4), \mathrm{A}^{P}(1,2)$;

$* *$ for subsidiary peaks, $U_{\text {iso }}=0.01$ (fixed). 
common feature in the refinement of TS-block structures, and the relevant distances were softly constrained to be equal to $1.58,1.60,1.61$ and $1.63,1.70 \AA$ in order to give us better stereochemical results. This constraint results in higher displacement parameters compared to other $\mathrm{O}$ atoms. Those constrained $\mathrm{Si}-\mathrm{O}$ distances can be detected easily in the corresponding table as they have an estimated standard deviation of $0.01 \AA$ (non-constrained distances have higher estimated standard deviations).

Details of the data collection and structure refinement are given in Table 2, final atom and subsidiary-atom parameters are given in Table 3, anisotropic displacement parameters for a group of cations in Table 4, selected interatomic distances and angles in Table 5, refined sitescattering values and assigned populations for selected sites in Table 6, bond-valence values in Table 7 and distances between $\mathrm{H}_{2} \mathrm{O}$ groups in Table 8. Lists of observed and calculated structure factors have been deposited with the Principal Editor of Mineralogical Magazine and are available from www.minersoc.org/pages/ e_journals/dep_mat_mm.html.

\section{Site-population assignment}

Here, we divide the cation sites (Table 3 ) into 3 groups: $M^{\mathrm{O}}$ sites of the $\mathrm{O}$ sheet, $M^{\mathrm{H}}$ and $S i$ sites of the $\mathrm{H}$ sheet, and peripheral $A^{P}$ sites; site labeling is in accord with Sokolova (2006). Consider first the $\mathrm{Ti}+\mathrm{Nb}$-dominant sites. We assign cations to these sites based on our knowledge from previous work on Ti-disilicate minerals: $\mathrm{Ti}(+\mathrm{Nb})$-dominant sites are always fully occupied. Table 1 shows that the $4 M^{\mathrm{H}}$ and $2 M^{\mathrm{O}}$ sites are occupied by
$4.14 \mathrm{Ti}, \quad 1.43 \mathrm{Nb}, 0.33 \mathrm{Mn}^{2+}, 0.06 \mathrm{Fe}^{3+}$ and $0.04 \mathrm{Al}$ (160.04 e.p.f.u.), and the aggregate refined scattering at these sites (159.8 e.p.f.u., Table 6) is in close accord with this composition. The refined site-scattering values at the $M^{\mathrm{H}}(1)$ and $M^{\mathrm{H}}(2)$ sites are significantly higher, 35.1 and 33.5 e.p.f.u., than at the $M^{\mathrm{O}}(1,2)$ and $M^{\mathrm{H}}(3,4)$ sites, 20.5-25.8 e.p.f.u., indicating that the heavier atoms, particularly $\mathrm{Nb}^{5+}$, must be assigned to the $M^{\mathrm{H}}(1)$ and $M^{\mathrm{H}}(2)$ sites. The mean bond lengths around the $4 M^{\mathrm{H}}$ and $2 M^{\mathrm{O}}$ sites vary from 1.92 to $2.05 \AA$. As the $M^{\mathrm{O}}(1)$ site has the longest bond length of $2.05 \AA$, we assign all $\mathrm{Mn}(\mathrm{r}=0.83 \AA)$ to this site: $0.67 \mathrm{Ti}+0.33 \mathrm{Mn}$ (aggregate $r_{\text {cat }}=0.679 \AA$ ). The mean bond length of the $M^{\mathrm{O}}(1)$ site agrees very well with the mean bond lengths of 2.043 and $2.056 \AA$ in sobolevite, $\mathrm{Na}_{12} \mathrm{Ca}(\mathrm{NaCaMn}) \mathrm{Ti}_{2}(\mathrm{TiMn})\left(\mathrm{Si}_{2} \mathrm{O}_{7}\right)_{2}\left(\mathrm{PO}_{4}\right)_{4} \mathrm{O}_{3} \mathrm{~F}_{3}$, where Ti-dominant sites in the $\mathrm{O}$ sheet have a significant Mn content (Sokolova et al., 2005). We assign $\mathrm{Ti}$ to the $M^{\mathrm{O}}(2)$ site which gives a good match between observed and calculated bond lengths (Table 6). Due to the difference in sitescattering for the [5]-coordinated $M^{\mathrm{H}}(3)$ and $M^{\mathrm{H}}(4)$ sites, 22.1 and 25.8 e.p.f.u. respectively, we assign the heavier scatterers, $\mathrm{Nb}$ and $\mathrm{Fe}^{3+}$, to the $M^{\mathrm{H}}(4)$ site and Ti with minor $\mathrm{Al}$ to the $M^{\mathrm{H}}(3)$ site.

Consider next the alkali-cation sites in the $\mathrm{O}$ sheet, $M^{\mathrm{O}}(3)-M^{\mathrm{O}}(8)$. Table 1 gives $3.71 \mathrm{Na}+$ $1.11 \mathrm{Mn}+0.46 \mathrm{Ca}=5.28$ a.p.f.u. with total scattering of 77.76 e.p.f.u. ( $0.5 \mathrm{Na}$ is assigned to the $A^{P}(4)$ site; see later discussion). Site-scattering for the alkali sites varies from 7.7 to 17 e.p.f.u. and the total scattering equals 77.6 e.p.f.u. This tells us that $\mathrm{Na}$ is a dominant cation species at all sites. The $M^{\mathrm{O}}(3)$ and $M^{\mathrm{O}}(4)$ sites have similar mean bond lengths, 2.48 and $2.45 \AA$ respectively,

TABLE 4. Displacement parameters $\left(\AA^{2}\right)$ for selected atoms in nechelyustovite.

\begin{tabular}{llllllrl}
\hline Atom & \multicolumn{1}{c}{$U_{11}$} & \multicolumn{1}{c}{$U_{22}$} & \multicolumn{1}{c}{$U_{33}$} & \multicolumn{1}{c}{$U_{23}$} & $U_{13}$ & $U_{12}$ & $U_{\text {eq }}$ \\
\hline $\mathrm{M}^{\mathrm{O}}(1)$ & $0.020(9)$ & $0.006(8)$ & $0.041(12)$ & $0.003(8)$ & $-0.013(8)$ & $0.001(7)$ & $0.022(5)$ \\
$\mathrm{M}^{\mathrm{O}}(2)$ & $0.027(12)$ & $0.022(11)$ & $0.023(14)$ & $0.002(10)$ & $-0.012(10)$ & $-0.002(9)$ & $0.025(6)$ \\
$\mathrm{M}^{\mathrm{O}}(7)$ & $0.015(14)$ & $0.021(15)$ & $0.029(19)$ & $0.009(14)$ & $0.014(13)$ & $0.008(12)$ & $0.021(8)$ \\
$\mathrm{M}^{\mathrm{O}}(8)$ & $0.005(13)$ & $0.014(14)$ & $0.04(2)$ & $-0.003(14)$ & $0.009(13)$ & $0.003(11)$ & $0.020(8)$ \\
$\mathrm{M}^{\mathrm{H}}(1)$ & $0.014(6)$ & $0.016(6)$ & $0.036(8)$ & $0.004(5)$ & $0.002(5)$ & $-0.003(5)$ & $0.022(3)$ \\
$\mathrm{M}^{\mathrm{H}}(2)$ & $0.017(7)$ & $0.022(7)$ & $0.037(10)$ & $0.008(7)$ & $0.006(7)$ & $-0.001(5)$ & $0.025(4)$ \\
$\mathrm{M}^{\mathrm{H}}(3)$ & $0.011(10)$ & $0.029(10)$ & $0.033(15)$ & $0.002(11)$ & $-0.005(10)$ & $-0.000(8)$ & $0.024(6)$ \\
$\mathrm{M}^{\mathrm{H}}(4)$ & $0.009(7)$ & $0.015(7)$ & $0.034(11)$ & $0.007(7)$ & $0.002(7)$ & $-0.000(6)$ & $0.019(4)$ \\
$\mathrm{A}^{P}(1)$ & $0.005(4)$ & $0.005(4)$ & $0.023(6)$ & $0.000(4)$ & $0.000(4)$ & $-0.001(3)$ & $0.011(2)$ \\
$\mathrm{A}^{P}(2)$ & $0.002(4)$ & $0.005(4)$ & $0.008(6)$ & $0.003(4)$ & $0.002(4)$ & $0.001(3)$ & $0.005(2)$ \\
& & & & & & & \\
\hline
\end{tabular}


whereas the $M^{\mathrm{O}}(5)-M^{\mathrm{O}}(8)$ sites have significantly shorter mean bond lengths of $\sim 2.32 \AA$, indicating that the larger cations, particularly $\mathrm{Na}$, must be assigned to the $M^{\mathrm{O}}(3)$ and $M^{\mathrm{O}}(4)$ sites, and $\mathrm{Na}$ plus the smaller cations, $\mathrm{Mn}$ and $\mathrm{Ca}$, must be assigned to the $M^{\mathrm{O}}(5)-M^{\mathrm{O}}(8)$ sites. This suggestion is supported by individual site-scattering values. As the $M^{\mathrm{O}}(3)$ and $M^{\mathrm{O}}(4)$ sites have sitescattering of 7.7 e.p.f.u., less than 11 e.p.f.u. for $\mathrm{Na}$; these sites must be partially occupied by $\mathrm{Na}$ and we assign $0.7 \mathrm{Na}+0.3 \square$ to each of these sites. This leaves us with $2.31 \mathrm{Na}+1.11 \mathrm{Mn}+$ $0.46 \mathrm{Ca}=3.88$ a.p.f.u. for the four sites, $M^{\mathrm{O}}(5)-$ $M^{\mathrm{O}}(8)$. These four sites split into two pairs, $M^{\mathrm{O}}(5)$ and $M^{\mathrm{O}}(6)$, each with site-scattering values of 17 e.p.f.u. and $M^{\mathrm{O}}(7)$ and $M^{\mathrm{O}}(8)$, each with values of 14.1 e.p.f.u. Therefore, we assign the heavier scatterers $(\mathrm{Mn}+\mathrm{Ca})$ to the $M^{\mathrm{O}}(5)$ and $M^{\mathrm{O}}(6)$ sites and the lighter scatterers to the $M^{\mathrm{O}}(7)$ and $M^{\mathrm{O}}(8)$ sites (Table 6). The occurrence of both $\mathrm{Na}$ and $\mathrm{Mn}^{2+}$ at one site is fairly common in Ti-disilicate minerals; it has previously been described in vuonnemite, $\mathrm{Na}_{7}\left(\mathrm{Na}, \mathrm{Mn}^{2+}\right)_{4} \mathrm{Ti}^{4+}\left(\mathrm{Nb}, \mathrm{Ti}^{4+}\right)_{2}$ $\left(\mathrm{Si}_{2} \mathrm{O}_{7}\right)_{2}\left(\mathrm{PO}_{4}\right)_{2} \mathrm{O}_{3}(\mathrm{~F}, \mathrm{OH})$ (Ercit et al., 1998), quadruphite, $\mathrm{Na}_{14} \mathrm{Ca}_{2} \mathrm{Ti}_{4}\left(\mathrm{Si}_{2} \mathrm{O}_{7}\right)_{2}\left(\mathrm{PO}_{4}\right)_{4} \mathrm{O}_{4} \mathrm{~F}_{2}$ (Sokolova and Hawthorne, 2001), polyphite, $\mathrm{Na}_{5}\left(\mathrm{Na}_{4} \mathrm{Ca}_{2}\right) \mathrm{Ti}_{2}\left(\mathrm{Si}_{2} \mathrm{O}_{7}\right)\left(\mathrm{PO}_{4}\right)_{3} \mathrm{O}_{2} \mathrm{~F}_{2}$ (Sokolova et al., 2005) and bornemanite, $\mathrm{Na}_{6} \mathrm{BaTi}_{2} \mathrm{Nb}$ $\left(\mathrm{Si}_{2} \mathrm{O}_{7}\right)_{2}\left(\mathrm{PO}_{4}\right) \mathrm{O}_{2}(\mathrm{OH}) \mathrm{F}$ (Cámara and Sokolova, 2007).

Consider last the four peripheral $A^{P}$ sites. The cations to be assigned to the $A^{P}(1-4)$ sites are $\mathrm{Ba}$, $\mathrm{Sr}, \mathrm{K}$ and $\mathrm{Na}$ (Table 1). The $<\mathrm{A}^{\mathrm{P}}(1-3)-\mathrm{O}>$ and $<\mathrm{A}^{\mathrm{P}}(4)-\mathrm{O}>$ distances are in the ranges $2.86-2.82$ and $2.60 \AA$ respectively. On the basis of their relative radii (Shannon, 1976), $\mathrm{Ba}, \mathrm{Sr}$ and $\mathrm{K}$ were assigned to the $A^{P}(1-3)$ sites, and $\mathrm{Na}$ was assigned to the $A^{P}(4)$ site, and the resulting aggregate site-populations are in accord with the aggregate refined site-scattering values (Table 6). At the $A^{P}$ sites, the maximum refined sitescattering values of 43.8 and 40.1 e.p.f.u. are at the $A^{P}(1,2)$ sites (Table 6 ); thus we assign these sites as filled mainly with $\mathrm{Ba}$, less $\mathrm{Sr}$ and $\mathrm{K}$. At the $A^{P}$ sites, the minimum refined site-scattering value of 12.5 e.p.f.u is at the $A^{P}$ (3) site (Table 6); thus we assign to this site a vacancy as the dominant species with lesser $\mathrm{Ba}$ and minor $\mathrm{Sr}$ and $\mathrm{K}$. The refined site-scattering value at the $A^{P}(4)$ site indicates partial occupancy by $\mathrm{Na}$, and $0.5 \mathrm{Na}$ $+0.5 \square$ were assigned on this basis (Table 6). This type of partial occupancy of the [8]coordinated $A^{P}(4)$ site by Na has been reported for epistolite (Sokolova and Hawthorne, 2004).

\section{Description of the structure}

\section{Site nomenclature}

As stated above, the cation sites are divided into 3 groups: $M^{\mathrm{O}}$ sites of the $\mathrm{O}$ sheet, $M^{\mathrm{H}}$ and $\mathrm{Si}$ sites of the $\mathrm{H}$ sheet and peripheral $A^{P}$ sites. Also in accord with Sokolova (2006), we label the anions $\mathrm{X}^{\mathrm{O}}, \mathrm{X}^{\mathrm{H}}$ and $\mathrm{X}^{P}$ (anions of $\mathrm{O}$ and $\mathrm{H}$ sheets and peripheral anions); $\mathrm{X}_{\mathrm{M}}^{\mathrm{O}}=$ common vertices of $\mathrm{M}^{\mathrm{O}}$ and $\mathrm{M}^{\mathrm{H}}$ polyhedra; $\mathrm{X}_{\mathrm{A}}^{\mathrm{O}}=$ common vertices of $\mathrm{M}^{\mathrm{O}}$ and $\mathrm{A}^{P}$ polyhedra; $\mathrm{X}_{\mathrm{M}}^{P}$ and $\mathrm{X}_{\mathrm{A}}^{P}=$ apical anions of $\mathrm{M}^{\mathrm{H}}$ and $\mathrm{A}^{P}$ polyhedra at the periphery of the TS block.

\section{Cation sites}

There are two distinct TS blocks not related by symmetry in the crystal structure of nechelyustovite. We label them $\mathrm{TS}_{1}$ (composed of $\mathrm{H}_{1} \mathrm{O}_{1} \mathrm{H}_{2}$ sheets) and $\mathrm{TS}_{2}$ (composed of $\mathrm{H}_{3} \mathrm{O}_{2} \mathrm{H}_{4}$ sheets). We will describe cation sites of the $\mathrm{O}$ sheets, $\mathrm{H}$ sheets and peripheral $A^{P}$ sites.

\section{$O$, sheet}

There are four cation sites in the $\mathrm{O}_{1}$ sheet: the Ti-dominant $M^{\mathrm{O}}(1)$ site and the alkali-cation $M^{\mathrm{O}}(3,5,6)$ sites (Fig. $3 a$ ). The $M^{\mathrm{O}}(1)$ site is occupied by $0.67 \mathrm{Ti}$ and $0.33 \mathrm{Mn}$, and is coordinated by four $\mathrm{O}$ atoms and two monovalent $\mathrm{X}_{\mathrm{A}}^{\mathrm{O}}$ anions (see section on Anion sites below) with $\mathrm{a}\left\langle\mathrm{M}^{\mathrm{O}}(1)-\varphi\right\rangle$ distance of $2.05 \AA(\varphi=$ unspecified anion) (Tables 3, 5, 6). The $M^{\mathrm{O}}(3)$ site is $70 \%$ occupied by $\mathrm{Na}$ (Table 6 ). The $M^{\mathrm{O}}(3)$ site is coordinated by six $\mathrm{O}$ atoms, with a $<\mathrm{M}^{\mathrm{O}}(3)-\mathrm{O}>$ distance of $2.48 \AA$. The $M^{\mathrm{O}}(5)$ and $M^{\mathrm{O}}(6)$ sites are occupied by $\mathrm{Na}$ and $\mathrm{M}^{2+}$ (= $\mathrm{Mn}>$ $\mathrm{Ca}$ ) in the ratio $1: 1$ (Table 6); they are coordinated by four $\mathrm{O}$ atoms and two $\mathrm{X}_{\mathrm{A}}^{\mathrm{O}}$ anions, with $\left\langle\mathrm{M}^{\mathrm{O}}(5)-\varphi>\right.$ and $\left\langle\mathrm{M}^{\mathrm{O}}(6)-\varphi>\right.$ distances of 2.29 and $2.35 \AA$, respectively. For the $\mathrm{O}_{1}$ sheet, the total of the $4 \mathrm{M}^{\mathrm{O}}$ cations is $\left[\left(\mathrm{Na}_{1.66} \mathrm{Mn}_{0.65} \mathrm{Ca}_{0.32} \square_{0.38}\right)\left(\mathrm{Ti}_{0.67} \mathrm{Mn}_{0.33}\right)\right]_{\Sigma 4}$, ideally $\left[\left(\mathrm{Na}_{1.5} \mathrm{Mn} \square 0.5\right) \mathrm{Ti}\right]_{\Sigma 4}$.

\section{$\mathrm{O}_{2}$ sheet}

There are four cation sites in the $\mathrm{O}_{2}$ sheet: the Ti-dominant $M^{\mathrm{O}}(2)$ site and the alkali-cation $M^{\mathrm{O}}(4,7,8)$ sites (Fig. $3 b$ ). The $M^{\mathrm{O}}(1)$ site is occupied solely by $\mathrm{Ti}$, and is coordinated by four $\mathrm{O}$ atoms and two monovalent $\mathrm{X}_{\mathrm{A}}^{\mathrm{O}}$ anions with $\mathrm{a}<\mathrm{M}^{\mathrm{O}}(2)-\varphi>$ distance of $1.97 \AA$ (Tables 3, 5, 6). The $M^{\mathrm{O}}(4)$ site is $70 \%$ occupied by $\mathrm{Na}$, as is the $M^{\mathrm{O}}(3)$ site in the $\mathrm{O}_{1}$ sheet (Table 6). The $M^{\mathrm{O}}(4)$ site is coordinated by six $\mathrm{O}$ atoms, with $<\mathrm{M}^{\mathrm{O}}(4)-\mathrm{O}>$ distance of $2.45 \AA$. The Na- 


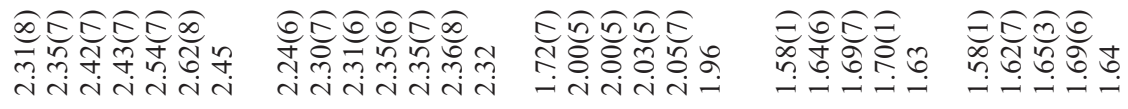

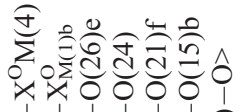

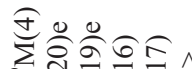

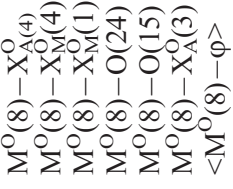

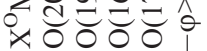

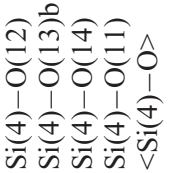

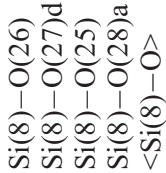
吉吉寺寺寺寺式

O $000 \sum$ 언

OิDEDEO 舟守寺 isicici

6क6ล6อ

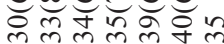

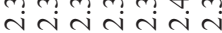

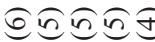

ชัo

도을

छછ‡

守导导导导

$\Sigma \Sigma \sum \Sigma \Sigma \sum$

- - - - - -

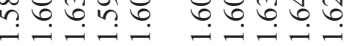

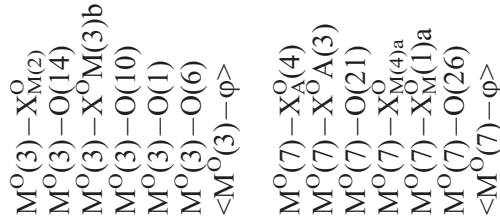

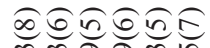

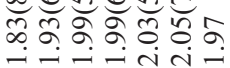

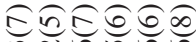

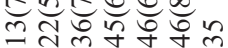

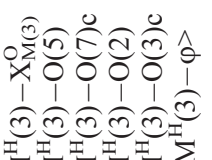

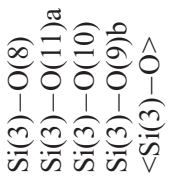

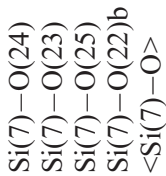

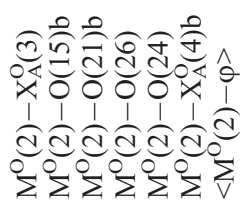

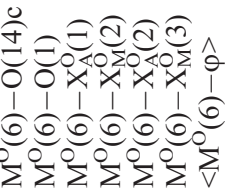

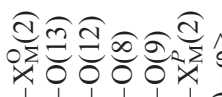
A 1 1 1 I

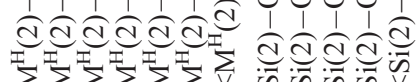

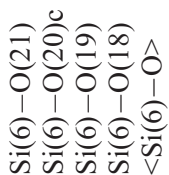

กิอย包 สুo कीE 60 ปี

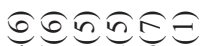
(⿱一𫝀口)

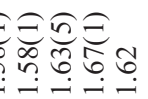
ลEEก

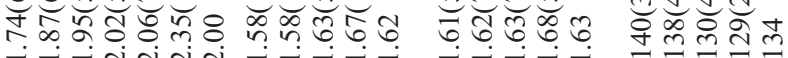

๙ิ犬土

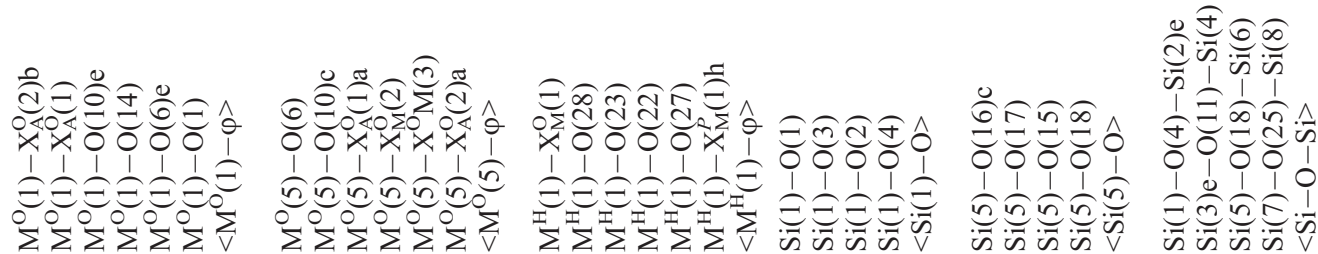




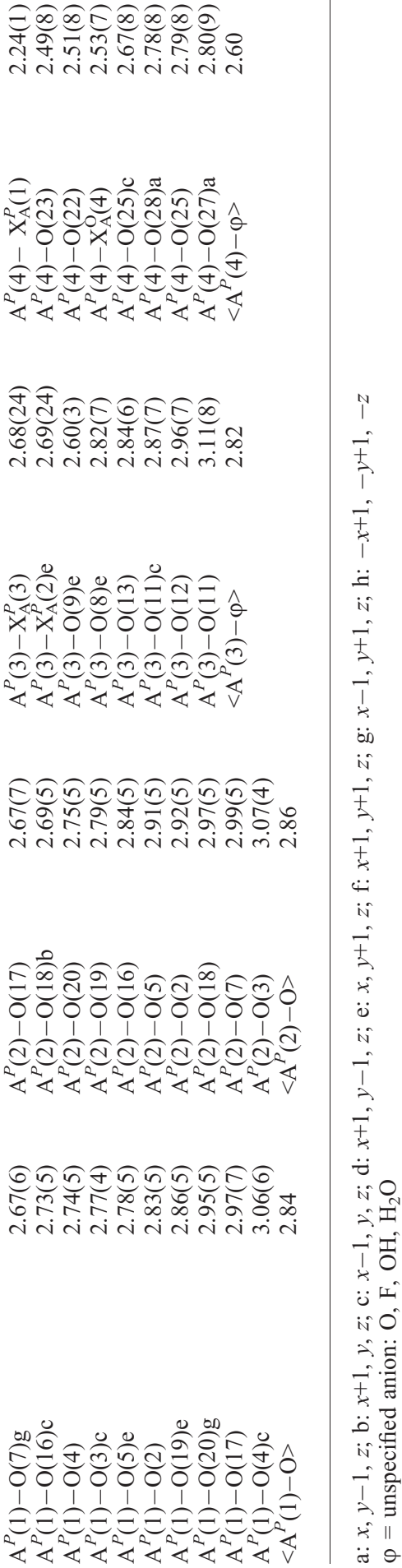

dominant $M^{\mathrm{O}}(7)$ and $M^{\mathrm{O}}(8)$ sites are occupied by $\mathrm{Na}$ and $\mathrm{M}^{2+}(=\mathrm{Mn}>\mathrm{Ca})$ (Table 6), they are coordinated by four $\mathrm{O}$ atoms and two $\mathrm{X}_{\mathrm{A}}^{\mathrm{O}}$ anions, with $<\mathrm{M}^{\mathrm{O}}(7)-\varphi>$ and $<\mathrm{M}^{\mathrm{O}}(8)-\varphi>$ distances of 2.35 and $2.32 \mathrm{~A}$, respectively. For the $\mathrm{O}_{2}$ sheet, the total of the $4 \mathrm{M}^{\mathrm{O}}$ cations is $\left[\left(\mathrm{Na}_{2.04} \mathrm{Mn}_{0.45}\right.\right.$ $\left.\left.\mathrm{Ca}_{0.08} \square 0.42\right) \mathrm{Ti}\right]_{\Sigma 4}$, ideally $\left[\left(\mathrm{Na}_{2} \mathrm{Mn}_{0.5} \square 0.5\right) \mathrm{Ti}\right]_{\Sigma 4}$.

\section{$H_{1}$ and $H_{2}$ sheets}

In the $\mathrm{H}_{1}$ and $\mathrm{H}_{2}$ sheets, there are four tetrahedrally coordinated sites occupied by $\mathrm{Si}$ with a $<\mathrm{Si}-\mathrm{O}>$ distance of 1.62 A (Table 5, Fig. $3 c, e)$. There are two $M^{\mathrm{H}}$ sites that occur in different $\mathrm{H}$ sheets of the $\mathrm{TS}_{1}$ block. In the $\mathrm{H}_{1}$ sheet, the [5]-coordinated $M^{\mathrm{H}}(3)$ site is occupied mainly by Ti (Table 6 ) and is coordinated by five $\mathrm{O}$ atoms, with $\mathrm{a}<\mathrm{M}^{\mathrm{H}}(1)-\mathrm{O}>$ distance of $1.92 \AA$; the very short $\mathrm{M}^{\mathrm{H}}(3)-\mathrm{X}_{\mathrm{M}}^{\mathrm{O}}(1)$ distance of $1.66 \AA$ (Table 5) is in accord with the structure topology of Group III minerals (Sokolova, 2006, fig. 32). In the $\mathrm{H}_{2}$ sheet, the [6]-coordinated Nb-dominant $M^{\mathrm{H}}(2)$ site is coordinated by five $\mathrm{O}$ atoms and an $\mathrm{H}_{2} \mathrm{O}$ group with a $<\mathrm{M}^{\mathrm{H}}(2)-\varphi>$ distance of $2.02 \AA$ (Table 5). The $\mathrm{H}_{2} \mathrm{O}$ group is the $\mathrm{X}_{\mathrm{M}}^{P}(2)$ anion in the terminology of Sokolova (2006)]. The shortest $\mathrm{M}^{\mathrm{H}}(2)-\mathrm{X}_{\mathrm{M}}^{\mathrm{O}}(2)$ distance is $1.76 \AA$ and the longest $\mathrm{M}^{\mathrm{H}}(2)-\mathrm{X}_{\mathrm{M}}^{P}(2)$ distance is $2.35 \AA$, from the $M^{\mathrm{H}}(2)$ site to an $\mathrm{H}_{2} \mathrm{O}$ group. For the $\mathrm{H}_{1}$ and $\mathrm{H}_{2}$ sheets, the total of $\mathrm{M}_{2}^{\mathrm{H}}$ cations is $\left(\mathrm{Ti}_{1.39} \mathrm{Nb}_{0.57} \mathrm{Al}_{0.04}\right)_{\Sigma 2}$, ideally $\mathrm{Ti}_{2}$ a.p.f.u.

\section{$\mathrm{H}_{3}$ and $\mathrm{H}_{4}$ sheets}

In the $\mathrm{H}_{3}$ and $\mathrm{H}_{4}$ sheets, four tetrahedrally coordinated sites are occupied by $\mathrm{Si}$ with a $<\mathrm{Si}-\mathrm{O}>$ distance of $1.63 \AA$ (Table 5, Fig. $3 d, f$ ). Two $M^{\mathrm{H}}$ sites occur in different $\mathrm{H}$ sheets of the $\mathrm{TS}_{2}$ block. In the $\mathrm{H}_{3}$ sheet, the [5]-coordinated $M^{\mathrm{H}}(4)$ site is occupied mainly by Ti (Table 6) and is coordinated by five $\mathrm{O}$ atoms, with a $<\mathrm{M}^{\mathrm{H}}(4)-\mathrm{O}>$ distance of $1.96 \AA$ and a short $\mathrm{M}^{\mathrm{H}}(4)-\mathrm{X}_{\mathrm{M}}^{\mathrm{O}}(4)$ distance of $1.72 \AA$ (Table 5). In the $\mathrm{H}_{4}$ sheet, the [6]-coordinated Nb-dominant $M^{\mathrm{H}}(1)$ site is coordinated by five $\mathrm{O}$ atoms and an $\mathrm{H}_{2} \mathrm{O}$ group with $\mathrm{a}<\mathrm{M}^{\mathrm{H}}(1)-\varphi>$ distance of $2.00 \AA$ (Table 5). The $\mathrm{H}_{2} \mathrm{O}$ group is the $\mathrm{X}_{\mathrm{M}}^{P}(1)$ anion in the terminology of Sokolova (2006). The shortest $\mathrm{M}^{\mathrm{H}}(2)-\mathrm{X}_{\mathrm{M}}^{\mathrm{O}}(2)$ distance is $1.74 \AA$ and the longest $\mathrm{M}^{\mathrm{H}}(1)-\mathrm{X}_{\mathrm{M}}^{P}(1)$ distance is $2.35 \AA$, from the $M^{\mathrm{H}}(1)$ site to an $\mathrm{H}_{2} \mathrm{O}$ group. The $\mathrm{H}_{3}$ and $\mathrm{H}_{4}$ sheets give $\mathrm{M}_{2}^{\mathrm{H}}=\left(\mathrm{Ti}_{1.08} \mathrm{Nb}_{0.86} \mathrm{Fe}_{0.06}^{3+}\right)_{\Sigma 2}$, ideally TiNb a.p.f.u.

\section{Peripheral $A^{P}$ sites}

In nechelyustovite, there are four distinct peripheral $A^{P}$ sites. The two [10]-coordinated 
TABLE 6. Refined site-scattering (e.p.f.u.) and assigned site-populations (a.p.f.u.) for nechelyustovite.

\begin{tabular}{lclccc}
\hline Site & $\begin{array}{c}\text { Refined } \\
\text { site-scattering }\end{array}$ & \multicolumn{1}{c}{ Site population } & $\begin{array}{c}\text { Calculated } \\
\text { site-scattering }\end{array}$ & $\begin{array}{c}\langle\mathrm{X}-\varphi\rangle_{\text {calc. }}{ }^{*} \\
(\mathrm{~A})\end{array}$ & $\begin{array}{c}\langle\mathrm{X}-\varphi\rangle_{\text {obs. }} \\
(\mathrm{A})\end{array}$ \\
\hline$M^{\mathrm{O}}(1)^{* *}$ & $22.8 * * *$ & $0.67 \mathrm{Ti}+0.33 \mathrm{Mn}$ & 23.0 & 2.05 & 2.05 \\
$M^{\mathrm{O}}(2)$ & 20.5 & $1.0 \mathrm{Ti}$ & 22.0 & 1.98 & 1.97 \\
$M^{\mathrm{O}}(3)$ & 7.7 & $0.7 \mathrm{Na}+0.3 \square$ & 7.7 & 2.40 & 2.48 \\
$M^{\mathrm{O}}(4)$ & 7.7 & $0.7 \mathrm{Na}+0.3 \square$ & 7.7 & 2.40 & 2.45 \\
$M^{\mathrm{O}}(5)$ & 17.0 & $0.46 \mathrm{Na}+0.37 \mathrm{Mn}+0.10 \mathrm{Ca}+0.08 \square$ & 16.3 & 2.32 & 2.29 \\
$M^{\mathrm{O}}(6)$ & 17.0 & $0.50 \mathrm{Na}+0.28 \mathrm{Mn}+0.22 \mathrm{Ca}$ & 16.9 & 2.33 & 2.35 \\
$M^{\mathrm{O}}(7)$ & 14.1 & $0.65 \mathrm{Na}+0.20 \mathrm{Mn}+0.08 \mathrm{Ca}+0.07 \square$ & 13.8 & 2.35 & 2.35 \\
$M^{\mathrm{O}}(8)$ & 14.1 & $0.69 \mathrm{Na}+0.26 \mathrm{Mn}+0.05 \square$ & 14.1 & 2.34 & 2.32 \\
$M^{\mathrm{H}}(1)$ & 35.1 & $0.66 \mathrm{Nb}+0.34 \mathrm{Ti}$ & 34.5 & 2.00 & 2.00 \\
$M^{\mathrm{H}}(2)$ & 33.5 & $0.57 \mathrm{Nb}+0.43 \mathrm{Ti}$ & 32.8 & 1.99 & 2.02 \\
${ }^{[5]} M^{\mathrm{H}}(3)$ & 22.1 & $0.96 \mathrm{Ti}+0.04 \mathrm{Al}$ & 21.6 & 1.95 & 1.92 \\
${ }^{[5]} M^{\mathrm{H}}(4)$ & 25.8 & $0.74 \mathrm{Ti}+0.20 \mathrm{Nb}+0.06 \mathrm{Fe}{ }^{3+}$ & 26.0 & 1.97 & 1.96 \\
${ }^{[10]} A^{P}(1)$ & 43.8 & $0.59 \mathrm{Ba}+0.23 \mathrm{Sr}+0.14 \mathrm{~K}+0.04 \square$ & 44.4 & 2.87 & 2.84 \\
${ }^{[10]} A^{P}(2)$ & 40.1 & $0.53 \mathrm{Ba}+0.21 \mathrm{Sr}+0.12 \mathrm{~K}+0.14 \square$ & 39.9 & 2.87 & 2.86 \\
${ }^{[8]} A^{P}(3)$ & 12.5 & $0.74 \square+0.16 \mathrm{Ba}+0.06 \mathrm{Sr}+0.04 \mathrm{~K}$ & 12.0 & 2.80 & 2.82 \\
${ }^{[8]} A^{P}(4)$ & 5.5 & $0.5 \mathrm{Na}+0.5 \square$ & 5.5 & 2.56 & 2.60 \\
& & & & &
\end{tabular}

* calculated by summing constituent ionic radii; values from Shannon (1976), X-cation, $\varphi=\mathrm{O},(\mathrm{OH}), \mathrm{F}, \mathrm{H}_{2} \mathrm{O}$; ** coordination number is given only for non-[6]-coordinated sites;

*** for each site, site-scattering was refined, adjusted in accord with chemical analysis (Table 1), and then fixed at the last stages of the refinement (see discussion in text).

sites, $A^{P}(1)$ and $A^{P}(2)$, are occupied mainly by Ba, $\mathrm{Ba}_{0.59} \mathrm{Sr}_{0.23} \mathrm{~K}_{0.14} \square 0.04$ and $\mathrm{Ba}_{0.53} \mathrm{Sr}_{0.21} \mathrm{~K}_{0.12} \square 0.14$ a.p.f.u. respectively. The $A^{P}(1)$ and $A^{P}(2)$ sites are coordinated by $\mathrm{O}$ atoms, with $<\mathrm{A}^{P}(1)-\mathrm{O}>$ and $<\mathrm{A}^{P}(1)-\mathrm{O}>$ distances of 2.84 and $2.86 \AA$, respectively. At the $A^{P}(1)$ and $A^{P}(2)$ sites, $\mathrm{Ba}^{2+}$ is the dominant cation and we write the ideal composition of these two sites as $\mathrm{Ba}_{2}$ a.p.f.u. The [8]-coordinated $A^{P}(3)$ site is dominated by a vacancy of $74 \%$ and its composition is as follows $\square 0.74 \mathrm{Ba}_{0.16} \mathrm{Sr}_{0.06} \mathrm{~K}_{0.04}$ (Table 6). The $A^{P}(3)$ site is coordinated by six $\mathrm{O}$ atoms and two $\mathrm{H}_{2} \mathrm{O}$ groups $\left[\mathrm{X}_{\mathrm{A}}^{P}(2)\right.$ and $\mathrm{X}_{\mathrm{A}}^{P}(3)$ anions in the terminology of Sokolova (2006)], with $\left\langle\mathrm{A}^{P}(3)-\varphi>=2.82 \AA\right.$. We write the ideal composition of the $A^{P}(3)$ site as $\square$ a.p.f.u. In the eleven TS block structures containing $\mathrm{Ba}$, perraultite, jinshajiangite, surkhobite, bafertisite, hejtmanite, yoshimuraite, bussenite, lamprophyllite, barytolamprophyllite, nabalamprophyllite and innelite, coordination numbers for $\mathrm{Ba}$ atoms are usually [9]-[12] (Sokolova, 2006, table 3; Sokolova et al., 2009). As for the [8]-coordinated $A^{P}(3)$ site, we presume that we have not been able to locate all coordinating anions for the $A^{P}(3)$ site because of the extreme cation-anion disorder in this particular part of the structure.
There is one peripheral $A^{P}(4)$ site occupied by $\mathrm{Na}_{0.5} \square 0.5$ a.p.f.u. and coordinated by seven $\mathrm{O}$ atoms and an $\mathrm{H}_{2} \mathrm{O}$ group [labeled $\mathrm{X}_{\mathrm{A}}^{P}(1)$ ], with $\left\langle\mathrm{A}^{P}(4)-\varphi>=2.60 \AA\right.$ (Table 5). Partial occupancy of a similar $A^{P}(3)$ site was observed in the crystal structure of epistolite: $\mathrm{Na}_{0.43} \square_{0.41} \mathrm{Ca}_{0.13} \mathrm{Mn}_{0.02},\left\langle\mathrm{~A}^{P}(3)-\varphi>=2.57 \AA\right.$ (Sokolova and Hawthorne, 2004). To summarize, the four peripheral sites ideally give: (1) $A^{P}(1)$ and $A^{P}(2)$ sites, $\mathrm{Ba}_{2}$ a.p.f.u.; (2) $A^{P}(3), \square$; (3) $A^{P}(4), \mathrm{Na}_{0.5} \square$ 0.5 a.p.f.u. $=\mathrm{Na}_{0.5} \mathrm{Ba}_{2} \square_{1.5}$.

We write the cation part of the formula as the sum of (1) the peripheral sites $+(2)$ four $\mathrm{H}$ sheets + (3) two O sheets: (1) $\mathrm{Na}_{0.5} \mathrm{Ba}_{2} \square_{1.5}+$ (2) $\left[\mathrm{Ti}_{2}+\right.$ $\mathrm{TiNb}]+(3)\left[\left(\mathrm{Na}_{1.5} \mathrm{Mn} \square_{0.5}\right) \mathrm{Ti}\right]+\left[\left(\mathrm{Na}_{2} \mathrm{Mn}_{0.5}\right.\right.$ $\square 0.5) \mathrm{Ti}]=\mathrm{Na}_{0.5} \mathrm{Ba}_{2} \square_{1.5}+\mathrm{Ti}_{3} \mathrm{Nb}+$ $\left(\mathrm{Na}_{3.5} \mathrm{Mn}_{1.5} \square\right) \mathrm{Ti}_{2}=\mathrm{Na}_{4} \mathrm{Ba}_{2} \mathrm{Mn}_{1.5} \square 2.5 \mathrm{Ti}_{5} \mathrm{Nb}$ with a total charge of +36 .

\section{Anion sites}

There are 28 anion sites, $\mathrm{O}(1)-\mathrm{O}(28)$, occupied by $\mathrm{O}$ atoms which form the tetrahedral coordination of the $\mathrm{Si}$ atoms (Tables 3, 5, 7). There are four sites, $\mathrm{X}_{\mathrm{M}}^{\mathrm{O}}(1)-\mathrm{X}_{\mathrm{M}}^{\mathrm{O}}(4)$, which are common anions for the $\mathrm{M}^{\mathrm{H}}$ polyhedra and three octahedra 


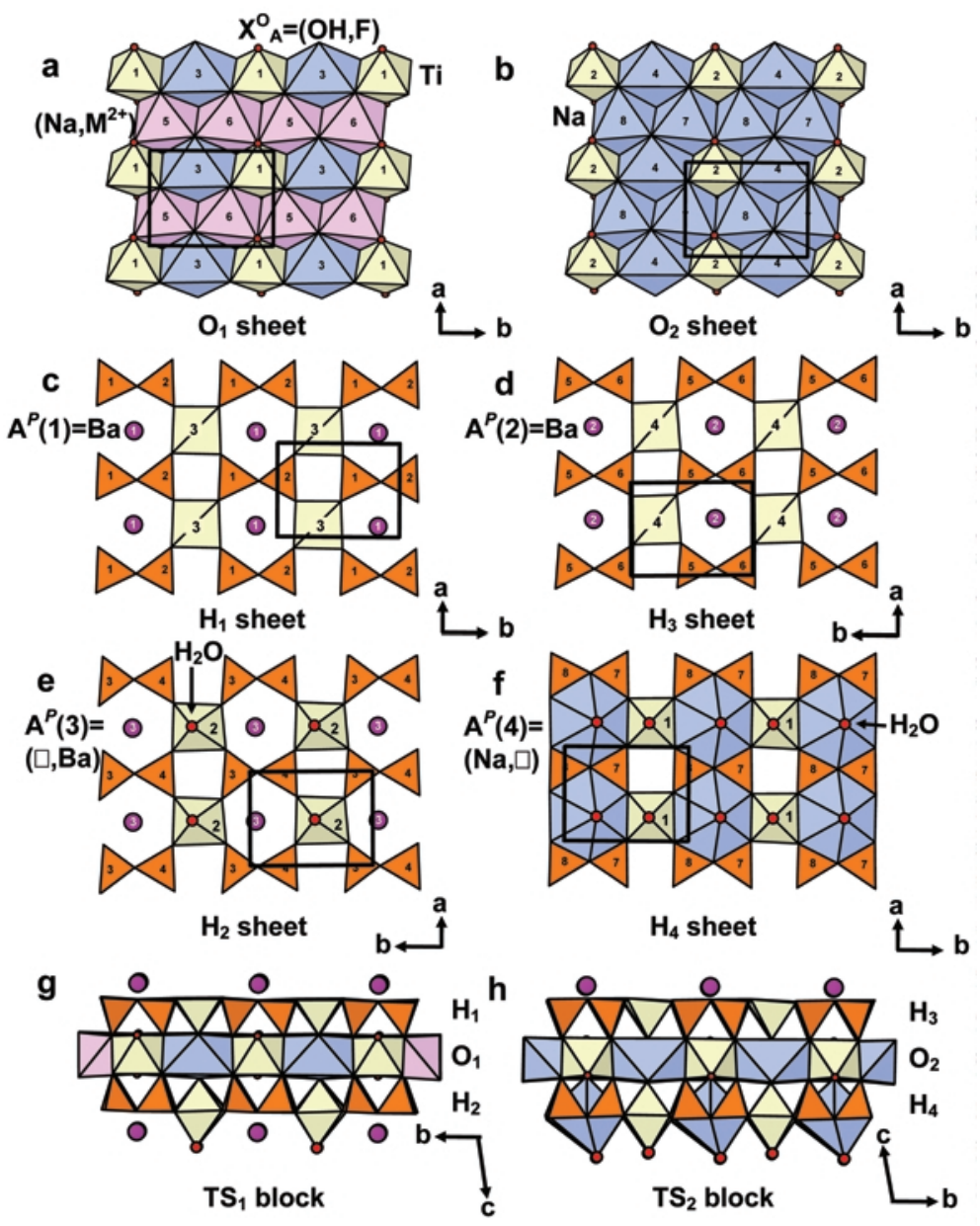

FIG. 3. The details of the TS block in the crystal structure of nechelyustovite: the close-packed octahedral (O) sheets $\mathrm{O}_{1}(a)$ and $\mathrm{O}_{2}(b)$; the heteropolyhedral $(\mathrm{H})$ sheets $\mathrm{H}_{1}(c), \mathrm{H}_{3}(d), \mathrm{H}_{2}(e)$ and $\mathrm{H}_{4}(f)$; the TS blocks $\operatorname{TS}_{1}(g)$ and $\operatorname{TS}_{2}(h)$ viewed down [100]. $\left(\mathrm{SiO}_{4}\right)$ tetrahedra are orange, $\mathrm{Ti}^{4+}$ - and $\mathrm{Nb}^{5+}$-dominant polyhedra are yellow, Na-dominant octahedra and [8]-coordinated $\mathrm{A}^{\mathrm{P}}(4)$ polyhedra are navy blue, $\mathrm{M}^{2+}$-dominant octahedra are pink, atoms at the $A^{P}$ sites are shown as raspberry spheres which are labeled 1,2 and 3 and correspond to $\mathrm{A}^{P}(1), \mathrm{A}^{P}(2)$ and $\mathrm{A}^{P}(3)$ atoms; monovalent $\mathrm{X}_{\mathrm{A}}^{\mathrm{O}}$ anions and $\mathrm{H}_{2} \mathrm{O}$ groups are shown as small and large red spheres. In $(a)$ and $(b)$, labels $1-8$ correspond to $\mathrm{M}^{\mathrm{O}}(1)-\mathrm{M}^{\mathrm{O}}(8)$ octahedra, respectively; in $(c)-(f)$, labels 1-8 (in orange) correspond to $\mathrm{Si}(1)-\mathrm{Si}(8)$ tetrahedra, respectively, and labels $1-4$ (in yellow) correspond to $\mathrm{M}^{\mathrm{H}}(1)-\mathrm{M}^{\mathrm{H}}(4)$ polyhedra respectively.

of the $\mathrm{O}$ sheet (Table 5). These anions receive bond valences of $1.75-2.07$ v.u. (valence units) (Table 7) and hence are $\mathrm{O}$ atoms (Table 3). There are four $X_{A}^{O}(1)-X_{A}^{O}(4)$ sites that are common anions for three octahedra of the $\mathrm{O}$ sheet [plus the $\mathrm{A}^{P}(4)$ cation in case of $\left.\mathrm{X}_{\mathrm{A}}^{\mathrm{O}}(1)\right]$. They receive bond valences of 1.04-1.37 v.u. (Table 7), and hence are monovalent anions (Table 3). The chemical analysis gives F 1.06 a.p.f.u. and we need $4-1.06$
$=2.94 \mathrm{OH}$ p.f.u. to fill these four sites (Table 1). Therefore, we assign $\mathrm{OH}_{2.94} \mathrm{~F}_{1.06}$ to the four $X_{\mathrm{A}}^{\mathrm{O}}(1)-X_{\mathrm{A}}^{\mathrm{O}}(4)$ sites. Ideally, the four $X_{\mathrm{A}}^{\mathrm{O}}$ sites give $(\mathrm{OH})_{3} \mathrm{~F}$ p.f.u. There are five $\mathrm{X}^{P}$ anions. The $\mathrm{X}_{\mathrm{M}}^{P}(1)$ and $\mathrm{X}_{\mathrm{M}}^{P}(2)$ are apical anions for $\mathrm{M}^{\mathrm{H}}(1)$ and $\mathrm{M}^{\mathrm{H}}(2)$ octahedra occupied by $\mathrm{Nb}$ and $\mathrm{Ti}$ (Table 5). They receive bond valence of 0.24 and 0.31 v.u. (Table 7) and they are $\mathrm{H}_{2} \mathrm{O}$ groups. The $\mathrm{X}_{\mathrm{A}}^{P}(1)$ is an apical anion for the $\mathrm{A}^{P}(4)$ polyhedron 


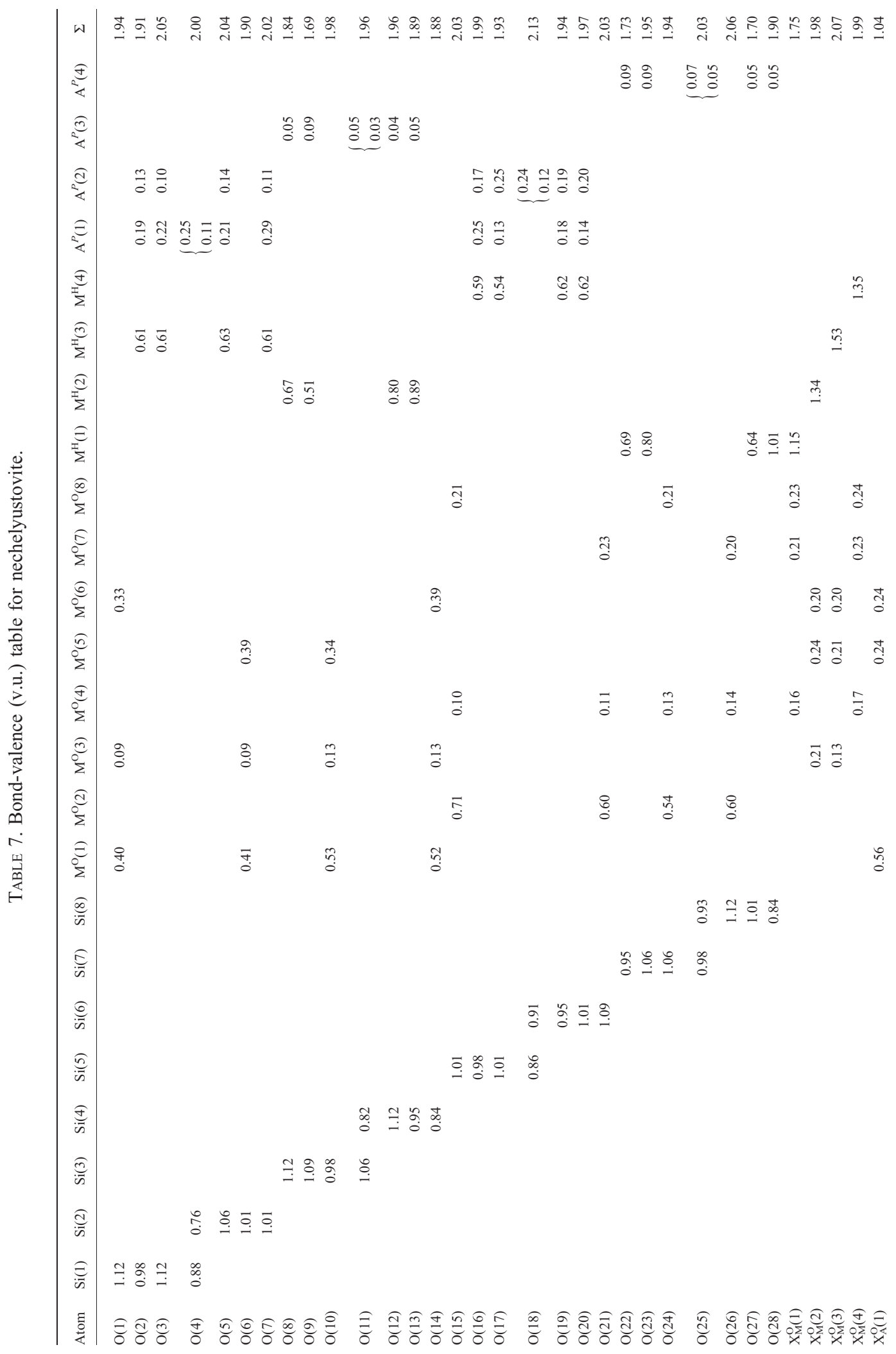


(Table 5), it receives bond valence of 0.14 v.u. (Table 7) and it is an $\mathrm{H}_{2} \mathrm{O}$ group. The $\mathrm{X}_{\mathrm{A}}^{P}(2)$ and $\mathrm{X}_{\mathrm{A}}^{P}(3)$ anions coordinate the $A^{P}(3)$ site which is occupied by $\mathrm{Ba}, \mathrm{Sr}$ and $\mathrm{K} \sim$ at $25 \%$ (Tables 5,6 ). They receive bond valence of 0.07 and 0.09 v.u. (Table 7) and are $\mathrm{H}_{2} \mathrm{O}$ groups; they give $\left(\mathrm{H}_{2} \mathrm{O}\right)_{0.5}$ p.f.u. There are three $\mathrm{H}_{2} \mathrm{O}$ groups, $\mathrm{W}(1)-\mathrm{W}(3)$ (Table 3), that are not bonded to any cation. The $W(1)$ and $W(2)$ sites are fully occupied and give $\left(\mathrm{H}_{2} \mathrm{O}\right)_{2}$ p.f.u. There is a short $\mathrm{W}(3)-\mathrm{W}(3)$ distance of $1.89 \AA$ and the $W(3)$ site is half occupied by $\mathrm{H}_{2} \mathrm{O}$, giving $\left(\mathrm{H}_{2} \mathrm{O}\right)_{0.5}$ p.f.u.

To conclude, we write the anion part of the structure as the sum of the anion sites: $\mathrm{O}_{28}(\mathrm{O}$ atoms of $\mathrm{Si}_{4}$ tetrahedra) $+\mathrm{O}_{4}\left[\mathrm{X}_{\mathrm{M}}^{\mathrm{O}}(1-4)\right]+$ $(\mathrm{OH})_{3} \mathrm{~F}\left[\mathrm{X}_{\mathrm{A}}^{\mathrm{O}}(1-4)\right]+\left(\mathrm{H}_{2} \mathrm{O}\right)_{2}\left[\mathrm{X}_{\mathrm{M}}^{\mathrm{P}}(1,2)\right]+\left(\mathrm{H}_{2} \mathrm{O}\right)$ $\left[\mathrm{X}_{\mathrm{A}}^{P}(1)\right]+\left(\mathrm{H}_{2} \mathrm{O}\right)_{0.5}\left[\mathrm{X}_{\mathrm{A}}^{P}(2,3)\right]+\left(\mathrm{H}_{2} \mathrm{O}\right)_{2.5}$ [W(1-3)]. We consider an $\left(\mathrm{Si}_{2} \mathrm{O}_{7}\right)$ group as a complex oxyanion and write the anion part of the nechelyustovite structure as $\left(\mathrm{Si}_{2} \mathrm{O}_{7}\right)_{4} \mathrm{O}_{4}(\mathrm{OH})_{3} \mathrm{~F}$ $\left(\mathrm{H}_{2} \mathrm{O}\right)_{6}$ with a total charge of -36 .

Based on the SREF results and bond-valence calculations, we write the ideal formula of nechelyustovite as the sum of cation and anion parts: $\mathrm{Na}_{4} \mathrm{Ba}_{2} \mathrm{Mn}_{1.5} \mathrm{Ti}_{5} \mathrm{Nb}\left(\mathrm{Si}_{2} \mathrm{O}_{7}\right)_{4} \mathrm{O}_{4}$ $(\mathrm{OH})_{3} \mathrm{~F}\left(\mathrm{H}_{2} \mathrm{O}\right)$, space group $P \overline{1}, Z=2$. The validity of the ideal formula is supported by good agreement between the charges for specific groups of cations in the ideal and empirical formulae: +11 for $\mathrm{Na}_{4} \mathrm{Ba}_{2} \mathrm{Mn}_{1.5}$ vs. +11.19 for $\left(\mathrm{Na}_{4.21} \mathrm{Mn}_{1.11}^{2+} \mathrm{Ca}_{0.46} \square_{1.22}\right)+\left(\mathrm{Ba}_{1.28} \mathrm{Sr}_{0.50}\right.$ $\left.\mathrm{K}_{0.30} \square 0.92\right)$; +25 for $\mathrm{Ti}_{5} \mathrm{Nb}$ vs. 24.66 for $\left(\mathrm{Ti}_{4.14} \mathrm{Nb}_{1.43} \mathrm{Mn}_{0.33}^{2+} \mathrm{Fe}_{0.06}^{3+} \mathrm{Al}_{0.04}\right)$. Note that the ideal formula gives $\mathrm{Ti}+\mathrm{Nb}=6$ a.p.f.u. per four $\left(\mathrm{Si}_{2} \mathrm{O}_{7}\right)$ groups which is equivalent to $\mathrm{Ti}+\mathrm{Nb}=3$ a.p.f.u. per two $\left(\mathrm{Si}_{2} \mathrm{O}_{7}\right)$ groups as in Group III.

\section{Structure topology}

\section{The TS block}

In the Ti-disilicate minerals (Sokolova, 2006), the TS block consists of $\mathrm{HOH}$ sheets where $\mathrm{H}$ is a heteropolyhedral sheet including $\left(\mathrm{Si}_{2} \mathrm{O}_{7}\right)$ groups, and $\mathrm{O}$ is a trioctahedral close-packed sheet. In nechelyustovite, there are two distinct TS blocks. The $\mathrm{TS}_{1}$ and $\mathrm{TS}_{2}$ blocks consist of $\mathrm{H}_{1} \mathrm{O}_{1} \mathrm{H}_{2}$ and $\mathrm{H}_{1} \mathrm{O}_{1} \mathrm{H}_{2}$ sheets respectively (Fig. 3). The $\mathrm{O}_{1}$ sheet comprises $\mathrm{M}^{\mathrm{O}}(1,3,5,6)$ octahedra (Fig. $3 a$ ) and its cation content is $\left[\left(\mathrm{Na}_{1.66} \mathrm{Mn}_{0.65} \mathrm{Ca}_{0.32} \square_{0.38}\right)\right.$ $\left.\left(\mathrm{Ti}_{0.67} \mathrm{Mn}_{0.33}\right)\right]$, ideally $\left[\left(\mathrm{Na}_{1.5} \mathrm{Mn} \square_{0.5}\right) \mathrm{Ti}\right]_{\Sigma 4}$ (4 a.p.f.u.). Note that a significant amount of $\mathrm{Mn}^{2+}$ at the $M^{\mathrm{O}}(1)$ site $(0.33$ a.p.f.u.) couples with significant amounts of $\mathrm{Mn}$ at three octahedral Na-dominant sites (0.65 a.p.f.u.). The $\mathrm{O}_{2}$ sheet 
comprises $\mathrm{M}^{\mathrm{O}}(2,4,7,8)$ octahedra (Fig. $\left.3 b\right)$ and its cation content is $\left[\left(\mathrm{Na}_{2.04} \mathrm{Mn}_{0.45} \mathrm{Ca}_{0.08} \square_{0.42}\right) \mathrm{Ti}\right]$, ideally $\left[\left(\mathrm{Na}_{2} \mathrm{Mn}_{0.5} \square 0.5\right) \mathrm{Ti}\right]$ (4 a.p.f.u.). Hence, the $\mathrm{O}_{1}$ sheet has a higher content of $\mathrm{Mn}^{2+}$ and the $\mathrm{O}_{2}$ sheet has a higher content of $\mathrm{Na}$. There are four distinct $\mathrm{H}$ sheets in nechelyustovite. In the $\mathrm{H}_{1}$ and $\mathrm{H}_{3}$ sheets, $\left(\mathrm{Si}_{2} \mathrm{O}_{7}\right)$ groups and [5]-coordinated Ti-dominant $\mathrm{M}^{\mathrm{H}}(3)$ and $\mathrm{M}^{\mathrm{H}}(4)$ polyhedra share common vertices to form the sheet (Fig. $3 c, d$ ) as in other Ti-disilicate minerals. In the $\mathrm{H}_{2}$ and $\mathrm{H}_{4}$ sheets, $\left(\mathrm{Si}_{2} \mathrm{O}_{7}\right)$ groups share common vertices with Nb-dominant $\mathrm{M}^{\mathrm{H}}(2)$ and $\mathrm{M}^{\mathrm{H}}(1)$ octahedra (Fig. $3 e, f)$. The topology of the four $\mathrm{H}$ sheets is identical except for the coordination of the $M^{\mathrm{H}}$ sites. In the $\mathrm{H}_{1,3}$ and $\mathrm{H}_{2}$ sheets, the peripheral $A^{P}$ sites are occupied by [10]-coordinated $\mathrm{Ba}$ and [8]coordinated $(\square, \mathrm{Ba})$ respectively (see discussion of the (I) block below). The $\mathrm{A}^{P}(1-3)$ cations are shifted from the plane of the $\mathrm{H}_{1-3}$ sheets to just above the centres of the large voids in the $\mathrm{H}$ sheets. The [8]-coordinated $\mathrm{A}^{P}(4)$ cations are located in the plane of the $\mathrm{H}_{4}$ sheet. The $\mathrm{H}$ and $\mathrm{O}$ sheets link via common vertices of $\mathrm{M}^{\mathrm{H}}$, Si and $\mathrm{M}^{\mathrm{O}}$ polyhedra to form the TS block which is parallel to (001) (Figs. $3 g, h$ ). In nechelyustovite, the TS block exhibits linkage 1 and stereochemistry typical for Group III (Sokolova, 2006): two H sheets connect to the $\mathrm{O}$ sheet such that two $\left(\mathrm{Si}_{2} \mathrm{O}_{7}\right)$ groups link to the trans edges of the Ti octahedron of the $\mathrm{O}$ sheet (cf. Fig. 1). In this case, the $\mathrm{H}_{1}$ and $\mathrm{H}_{2}\left(\mathrm{H}_{3}\right.$ and $\left.\mathrm{H}_{4}\right)$

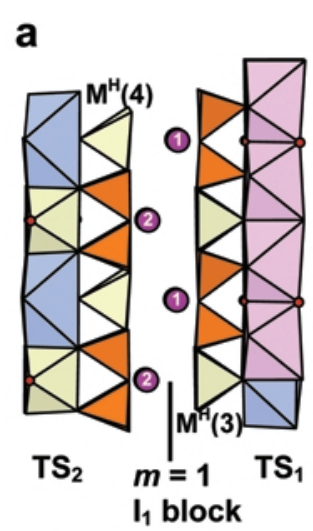

C

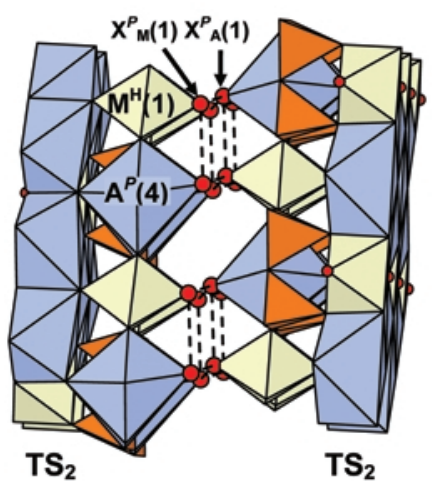

b
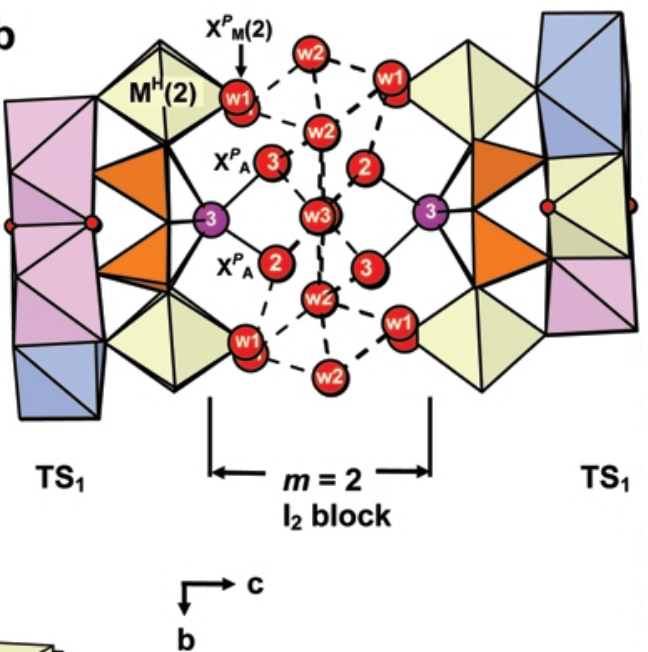

FIG. 4. Details of linkage of TS blocks in the crystal structure of nechelyustovite: the intermediate (I) blocks $\mathbf{I}_{1}(a)$ and $\mathbf{I}_{2}(b)$; linkage of two $\mathrm{TS}_{2}$ blocks through hydrogen bonds $(c)$. Legend as in Fig. $3, \mathrm{~m}=$ number of cation layers in the $\mathbf{I}$ block, solid black lines show position of $\mathrm{m}$ layers in $(a)$ and $(b)$; in $(b)$, bonds from the $\mathrm{A}^{P}(3)$ atom to coordinating anions are shown as black dashed lines; $\mathrm{H}_{2} \mathrm{O}$ groups coordinating $\mathrm{M}^{\mathrm{H}}(2)$ and $\mathrm{A}^{P}(3)$ atoms are labelled $\mathrm{X}_{\mathrm{M}}^{P}(2)$ and $2\left[=\mathrm{X}_{\mathrm{A}}^{P}(2)\right]$ and $3\left[=\mathrm{X}_{\mathrm{A}}^{P}(3)\right]$, respectively, and $\mathrm{H}_{2} \mathrm{O}$ groups which do not coordinate cations are labelled W1, W2 and W3. Distances in the range 2.5-3.4 A between $\mathrm{H}_{2} \mathrm{O}$ groups are shown as black dashed lines and they are possible directions for hydrogen bonds. 
sheets are related by a pseudo-mirror plane $(\mathrm{m})$ coinciding with the plane of the $\mathrm{O}$ sheet.

\section{The I blocks}

In nechelyustovite, the TS blocks do not link directly through the apical vertices of the $\mathrm{M}^{\mathrm{H}}$ polyhedra; they alternate with intermediate (I) blocks, $\mathbf{I}_{\mathbf{1}}$ and $\mathbf{I}_{\mathbf{2}}$. An $\mathbf{I}$ block is always intercalated between two TS blocks and cations of the I block form close-packed I layers parallel to the TS block where $m=$ number of those layers (Sokolova, 2006).

A layer of $\mathrm{A}^{P}(1)$ and $\mathrm{A}^{P}(2)$ atoms forms the $\mathbf{I}_{\mathbf{1}}$ block between adjacent $\mathrm{TS}_{1}$ and $\mathrm{TS}_{2}$ blocks (Fig. $4 a$ ). In the $\mathbf{I}_{\mathbf{1}}$ block, $\mathrm{A}^{P}(1,2)$ atoms are arranged in a close-packed fashion where each atom is surrounded by six others at approximately equal distances of $5 \AA$. The composition of the $\mathbf{I}_{1}$ block is $\mathrm{A}_{2}^{P}$ or ideally $\mathrm{Ba}_{2}$.

The $\mathbf{I}_{\mathbf{2}}$ block is composed mainly of $\mathrm{H}_{2} \mathrm{O}$ groups and two $\mathbf{I}$ layers $(m=2)$ of cations occupied at $25 \%$ (Fig. $4 b$ ). The $\mathbf{I}_{\mathbf{2}}$ block occurs between adjacent $\mathrm{TS}_{1}$ blocks. The two I layers of $\mathrm{A}^{P}(3)$ atoms are parallel to (001) and are related by an inversion centre. Therefore the topology and chemical composition of these two I layers of $\mathrm{A}^{P}(3)$ polyhedra are identical. There are two types of $\mathrm{H}_{2} \mathrm{O}$ groups in the $\mathbf{I}_{\mathbf{2}}$ block, one bonded and the other not bonded to cations. Three $\mathrm{H}_{2} \mathrm{O}$ groups are ligands of $\mathrm{M}^{\mathrm{H}}(2)$ and $\mathrm{A}^{P}(3)$ cations; they occur at the $X_{\mathrm{M}}^{P}(2), X_{\mathrm{A}}^{P}(2)$ and $X_{\mathrm{A}}^{P}(3)$ sites occupied at 100 , 25 and $25 \%$ respectively and belong to the $\mathrm{TS}_{1}$ block (Fig. 4b). Three $\mathrm{H}_{2} \mathrm{O}$ groups, labeled $\mathrm{W}(1-3)$ (Table 3, Fig. 4b), are not bonded to any cation; they occur in the intermediate space between two $\mathrm{TS}_{1}$ blocks and give in total $\left(\mathrm{H}_{2} \mathrm{O}\right)_{2.5}$. We write the composition of the $\mathbf{I}_{2}$ block as the sum of two $A^{P}(3)$ sites and three $W$ sites: $\left(\square_{1.48} \mathrm{Ba}_{0.32} \mathrm{Sr}_{0.12} \mathrm{~K}_{0.08}\right)\left(\mathrm{H}_{2} \mathrm{O}\right)_{5}$. There is one $\mathbf{I}_{2}$ block per $c$ cell-parameter and this gives $\left(\square 0.74 \mathrm{Ba}_{0.16} \mathrm{Sr}_{0.06} \mathrm{~K}_{0.04}\right)\left(\mathrm{H}_{2} \mathrm{O}\right)_{2.5}$ p.f.u.

There are no additional cations in the intermediate space between two $\mathrm{TS}_{2}$ blocks

TABLE 8. The $\mathrm{O}-\mathrm{O}$ distances $(\AA)$ for $\mathrm{H}_{2} \mathrm{O}$ groups in the $\mathbf{I}_{2}$ block.

\begin{tabular}{|c|c|c|c|c|c|c|}
\hline & $\mathrm{X}_{\mathrm{M}}^{P}(2)$ & $\mathrm{X}_{\mathrm{A}}^{P}(2)^{*}$ & $\mathrm{X}_{\mathrm{A}}^{P}(3)^{*}$ & $\mathrm{~W}(1)$ & $\mathrm{W}(2)$ & $\mathrm{W}(3)^{*}$ \\
\hline $\mathrm{X}_{\mathrm{M}}^{P}(2)$ & $2.83(7)$ & & $2.42(7)$ & $2.74(10)$ & & \\
\hline $\mathrm{X}_{\mathrm{M}}^{P}(2) \mathrm{a}$ & & & & $2.76(10)$ & & \\
\hline $\mathrm{X}_{\mathrm{A}}^{P}(2)$ & & $2.83(7)$ & & $3.04(7)$ & & $(1.87)^{*}$ \\
\hline $\mathrm{X}_{\mathrm{A}}^{P}(2) \mathrm{b}$ & & & & & $2.49(7)$ & \\
\hline $\mathrm{X}_{\mathrm{A}}^{P}(2) \mathrm{c}$ & & & $2.72 * *$ & & & \\
\hline $\mathrm{X}_{\mathrm{A}}^{P}(2) \mathrm{d}$ & & & & & & $3.04 * *$ \\
\hline $\mathrm{X}_{\mathrm{A}}^{P}(3)$ & $2.42(7)$ & & & & & \\
\hline $\mathrm{X}_{\mathrm{A}}^{P}(3) \mathrm{a}$ & & & & $2.40(7)$ & & \\
\hline $\mathrm{X}_{\mathrm{A}}^{P}(3) \mathrm{c}$ & & $2.72 * *$ & & & & $(2.24)^{*}$ \\
\hline $\mathrm{X}_{\mathrm{A}}^{P}(3) \mathrm{f}$ & & & & & $2.73(7)$ & \\
\hline $\mathrm{W}(1)$ & $2.74(10)$ & $3.04(7)$ & & & & \\
\hline $\mathrm{W}(1) \mathrm{b}$ & $2.76(10)$ & & $2.40(7)$ & & $2.65(10)$ & \\
\hline $\mathrm{W}(1) \mathrm{c}$ & & & & & $2.46(10)$ & \\
\hline$W(2) c$ & & & & $2.46(10)$ & & \\
\hline $\mathrm{W}(2) \mathrm{a}$ & & $2.49(7)$ & & $2.65(10)$ & & $2.77(7)$ \\
\hline $\mathrm{W}(2) \mathrm{e}$ & & & & & & $2.43(7)$ \\
\hline$W(2) f$ & & & $2.73(7)$ & & $2.69(13)$ & \\
\hline W(3) & & $(1.87)^{*}$ & & & & \\
\hline$W(3) b$ & & & & & $2.77(7)$ & \\
\hline$W(3) c$ & & & $(2.24) * *$ & & & \\
\hline W(3)e & & & & & $2.43(6)$ & \\
\hline$W(3) d$ & & $3.04 * *$ & & & & $(1.89)^{*}$ \\
\hline
\end{tabular}

a: $x-1, y, z$; b: $x+1, y, z$; c: $-x+1,-y+1,-z+1 ; \mathrm{d}:-x,-y,-z+1 ; e:-x+1,-y,-z+1 ; \mathrm{f}:-x+2,-y+1,-z+1$

* The $X_{\mathrm{A}}^{P}(2)$ and $X_{\mathrm{A}}^{P}(3)$ sites are $25 \%$ and $W(3)$ site is $50 \%$ occupied by $\mathrm{H}_{2} \mathrm{O}$ groups and short $\mathrm{O}-\mathrm{O}$ distances given in brackets must not be taken into account.

** These distances do not have e.s.d. at the coordinates for the $X_{\mathrm{A}}^{P}(2), X_{\mathrm{A}}^{P}(3)$ and $W(3)$ sites were fixed at the last stages of the refinement (see Table 3). 
(Fig. 4c). Two $\mathrm{TS}_{2}$ blocks connect via hydrogen bonding between $\mathrm{H}_{2} \mathrm{O}$ groups [at $X_{\mathrm{M}}^{P}(1)$ and $X_{\mathrm{A}}^{P}(1)$ sites] which link to $\mathrm{M}^{\mathrm{H}}(1)$ and $\mathrm{A}^{P}(4)$ cations as in epistolite (Sokolova and Hawthorne, 2004) and murmanite (Cámara et al., 2008) (see discussion below).

\section{Hydrogen bonding}

Because of extensive cation and anion disorder in the crystal structure of nechelyustovite, we experienced difficulties locating the $\mathrm{O}$ atoms of $\mathrm{H}_{2} \mathrm{O}$ groups in the $\mathbf{I}_{2}$ block and we do not feel that it is appropriate to discuss details of hydrogen bonding. However, to show that $\mathrm{H}_{2} \mathrm{O}$ groups in the $\mathbf{I}_{\mathbf{2}}$ block occur at distances suitable for possible hydrogen bonding, we report $\mathrm{O}-\mathrm{O}$ distances less than $3.2 \AA$ between $\mathrm{O}$ atoms of $\mathrm{H}_{2} \mathrm{O}$ groups for the $\mathbf{I}_{\mathbf{2}}$ block (Table 8). Inspection of Table 8 gives $\mathrm{O}-\mathrm{O}$ distances from 2.42 to $3.04 \AA$ (Fig. 4b).

Two more sites occupied by $\mathrm{H}_{2} \mathrm{O}$ groups $X_{\mathrm{M}}^{P}(1)$ and $X_{\mathrm{A}}^{P}(1)-$ coordinate $\mathrm{M}^{\mathrm{H}}(1)$ and $\mathrm{A}^{P}(4)$ cations (see discussion above). The $X_{\mathrm{M}}^{P}(1)$ site is surrounded by three $X_{\mathrm{A}}^{P}(1)$ sites with distances between them (and vice versa) of 2.77, 2.91 and
$3.02 \AA$ (Fig. 4c). They are suitable for hydrogen bonding.

\section{The general structure}

The crystal structure of nechelyustovite (Fig. $5 a$ ) consists of TS and I blocks alternating along c. There are four TS blocks and three $\mathbf{I}$ blocks, $2 \mathbf{I}_{1}$ and $\mathbf{I}_{2}$, per $c$ cell-parameter. They occur in the following sequence: $\mathrm{TS}_{2}-\mathbf{I}_{1}-\mathrm{TS}_{1}-\mathbf{I}_{2}-\mathrm{TS}_{1}$ $-\mathbf{I}_{1}-\mathrm{TS}_{2}$. Furthermore, adjacent $\mathrm{TS}_{2}$ blocks connect through hydrogen bonding between $\mathrm{H}_{2} \mathrm{O}$ groups (Figs $4 c, 5 a$ ). Nechelyustovite is the second Ti-disilicate mineral [after bornemanite (Cámara and Sokolova, 2007)] with two different types of $\mathbf{I}$ block. Note that the $\mathbf{I}_{2}$ block has an inversion centre whereas the $\mathbf{I}_{1}$ block does not. There are two distinct TS blocks, $\mathrm{TS}_{1}$ and $\mathrm{TS}_{2}$, not related by an inversion centre. Nechelyustovite is the only Ti-disilicate mineral so far known with two different types of linkage of TS blocks: (1) through the $\mathbf{I}_{1}$ and $\mathbf{I}_{2}$ blocks with layers of cations (although not a major constituent but interstitial cations are still present in the $\mathbf{I}_{2}$ block), and (2) via hydrogen bonding. The TS block exhibits the stereochemistry of Group III

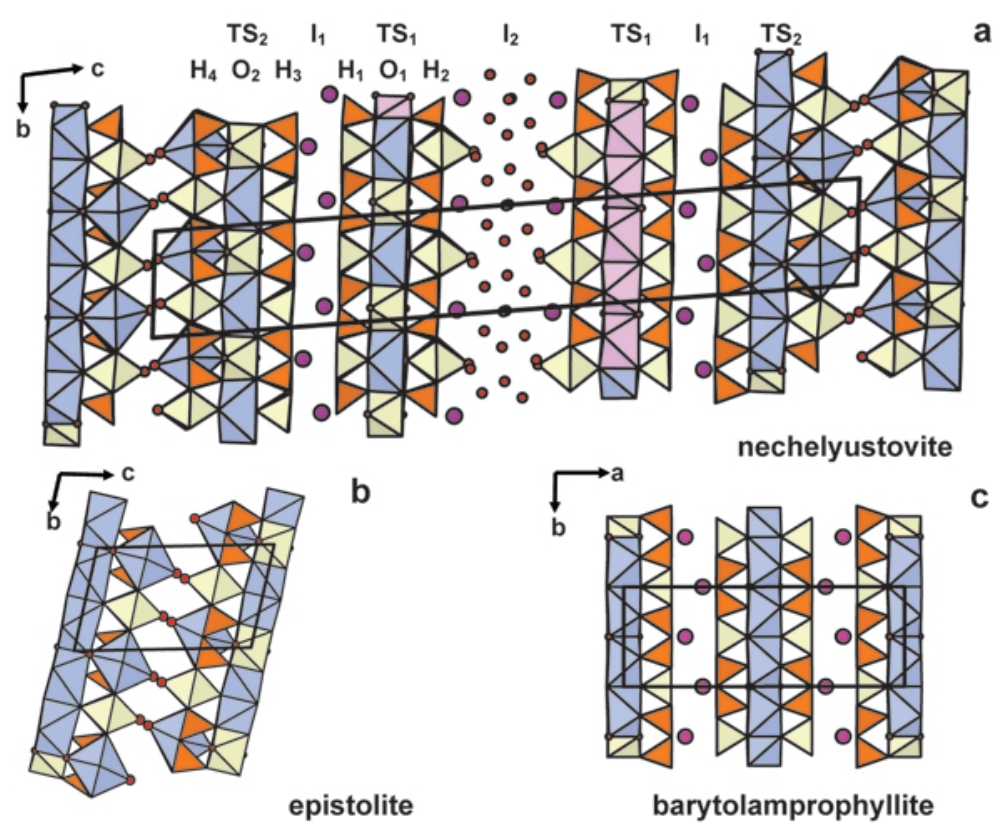

FIG. 5. (a) The crystal structure of: nechelyustovite projected onto (100). (b) Related mineral, epistolite, projected onto (100). (c) Barytolamprophyllite projected onto (001). Legend as in Fig. 3. 
where Ti equals 3 a.p.f.u., and this is the key to understanding the relation between nechelyustovite and other Ti-disilicate minerals.

\section{The structural and ideal formulae of nechelyustovite}

Above, we wrote the ideal formulae of nechelyustovite based on the occupancies of the cation and anion sites. Here, we write the ideal structural formula of nechelyustovite in accord with Sokolova (2006): the formula for the TS block of Group III minerals is $\mathrm{A}_{2}^{P} \mathrm{~B}_{2}^{P} \mathrm{M}_{2}^{\mathrm{H}} \mathrm{M}_{4}^{\mathrm{O}}$ $\left(\mathrm{Si}_{2} \mathrm{O}_{7}\right)_{2} \mathrm{X}_{4}^{\mathrm{O}} \mathrm{X}_{\mathrm{M} 2}^{P} \mathrm{X}_{\mathrm{A} 2}^{P}$, in which $\mathrm{A}^{P}$ and $\mathrm{B}^{P}$ are cations at the peripheral $(P)$ sites; $\mathrm{M}^{\mathrm{H}}$ and $\mathrm{M}^{\mathrm{O}}$ are cations of the $\mathrm{H}$ and $\mathrm{O}$ sheets; $\mathrm{X}^{\mathrm{O}}$ are anions of the $\mathrm{O}$ sheet; $\mathrm{X}_{\mathrm{M}}^{P}$ and $\mathrm{X}_{\mathrm{A}}^{P}$ are apical anions of the $\mathrm{M}^{\mathrm{H}}$ and $\mathrm{A}^{P}$ cations at the periphery of the TS block. Note that we write the formula per two minimal cells based on the $\mathbf{t}_{1}$ and $\mathbf{t}_{2}$ translations. Therefore, the ideal structural formula for nechelyustovite is of the form

$$
\mathrm{A}_{4}^{P} \mathrm{~B}_{4}^{P} \mathrm{M}_{4}^{\mathrm{H}} \mathrm{M}_{8}^{\mathrm{O}}\left(\mathrm{Si}_{2} \mathrm{O}_{7}\right)_{4} \mathrm{X}_{8}^{\mathrm{O}} \mathrm{X}_{\mathrm{M} 4}^{P} \mathrm{X}_{\mathrm{A} 4}^{P}
$$

In nechelyustovite, $\mathrm{A}_{4}^{P}=\mathrm{A}^{P}(1)+\mathrm{A}^{P}(2)+$ $\mathrm{A}^{P}(3)+\mathrm{A}^{P}(4)=\mathrm{Ba}+\mathrm{Ba}+\square+\left(\mathrm{Na}_{0.5} \square_{0.5}\right) ; \mathrm{B}_{4}^{P}$ $=0 ; \mathrm{M}_{4}^{\mathrm{H}}=\mathrm{M}^{\mathrm{H}}(1)+\mathrm{M}^{\mathrm{H}}(2)+\mathrm{M}^{\mathrm{H}}(3)+\mathrm{M}^{\mathrm{H}}(4)=$ $\mathrm{Ti}_{3} \mathrm{Nb} ; \quad \mathrm{M}_{8}^{\mathrm{O}}=\left(\mathrm{Na}_{3.5} \mathrm{Mn}_{1.5} \square\right) \mathrm{Ti}_{2} ; \mathrm{X}_{8}^{\mathrm{O}}=\mathrm{O}_{4}$ $(\mathrm{OH})_{3} \mathrm{~F} ; \mathrm{X}_{\mathrm{M} 4}^{P}$ and $\mathrm{X}_{\mathrm{A} 4}^{P}=\left(\mathrm{H}_{2} \mathrm{O}\right)_{2}$ and $\left(\mathrm{H}_{2} \mathrm{O}\right)_{1.5}=$ $\left(\mathrm{H}_{2} \mathrm{O}\right)_{3.5}$. Hence, we write the ideal composition of the two TS blocks as $\left(\mathrm{Na}_{0.5} \square_{0.5}\right) \mathrm{Ba}_{2} \mathrm{Ti}_{3} \mathrm{Nb}$ $\left(\mathrm{Na}_{3.5} \mathrm{Mn}_{1.5} \square\right) \mathrm{Ti}_{2}\left(\mathrm{Si}_{2} \mathrm{O}_{7}\right)_{4} \mathrm{O}_{4}(\mathrm{OH})_{3} \mathrm{~F}, \quad Z=2$. There are two $\mathbf{I}$ blocks in nechelyustovite: the $\mathbf{I}_{1}$ block comprises the $\mathrm{A}^{P}(1,2)$ atoms, which have been already counted in the formula of TS block; the $\mathbf{I}_{2}$ block includes $A^{P}(3)$ atoms and $\left(\mathrm{H}_{2} \mathrm{O}\right)$ groups and we write its composition as $\left(\mathrm{H}_{2} \mathrm{O}\right)_{2.5}$ p.f.u. (Table 9).

We sum the TS and $\mathbf{I}_{2}$ blocks (the $\mathbf{I}_{1}$ block consists of the $\mathrm{A}^{P}(1,2)$ atoms and they have been already included in the formula of the TS block) to write the ideal structural and mineral formula for nechelyustovite: $\left(\mathrm{Na}_{0.5} \square 0.5\right)\left(\mathrm{Ba}_{2} \square\right) \mathrm{Ti}_{3} \mathrm{Nb}$ $\left(\mathrm{Na}_{3.5} \mathrm{Mn}_{1.5} \square\right) \mathrm{Ti}_{2}\left(\mathrm{Si}_{2} \mathrm{O}_{7}\right)_{4} \mathrm{O}_{4}(\mathrm{OH})_{3} \mathrm{~F}\left(\mathrm{H}_{2} \mathrm{O}\right)_{3.5}$ $\left(\mathrm{H}_{2} \mathrm{O}\right)_{2.5}$ and $\mathrm{Na}_{4} \mathrm{Ba}_{2} \mathrm{Mn}_{1.5} \square_{2.5} \mathrm{Ti}_{5} \mathrm{Nb}\left(\mathrm{Si}_{2} \mathrm{O}_{7}\right)_{4}$ $\mathrm{O}_{4}(\mathrm{OH})_{3} \mathrm{~F}\left(\mathrm{H}_{2} \mathrm{O}\right)_{6}$ respectively, with $Z=2$; these may compared with the empirical formula resulting from the electron microprobe analysis: $\left(\mathrm{Na}_{4.21} \mathrm{Mn}_{1.11}^{2+} \mathrm{Ca}_{0.46} \square_{1.22}\right)_{\Sigma 7.00}\left(\mathrm{Ba}_{1.28} \mathrm{Sr}_{0.50} \mathrm{~K}_{0.30}\right.$ $\left.\square_{0.92}\right)_{\Sigma 3.00}\left(\mathrm{Ti}_{4.14} \mathrm{Nb}_{1.43} \mathrm{Mn}_{0.33}^{2+} \mathrm{Fe}_{0.06}^{3+} \mathrm{Al}_{0.04}\right)_{\Sigma 6}$ $\left(\mathrm{Si}_{8.03} \mathrm{O}_{28}\right) \mathrm{O}_{3.99}\left[(\mathrm{OH})_{2.94} \mathrm{~F}_{1.06}\right]_{\Sigma 4.00}\left(\mathrm{H}_{2} \mathrm{O}\right)_{6.01}$.

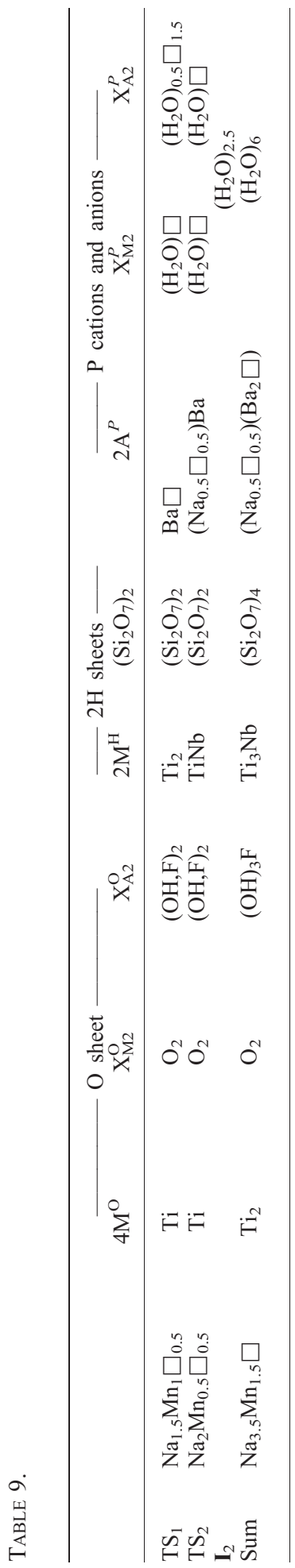




\section{Related minerals}

There are four types of crystal structure based on self-linkage of TS blocks (Sokolova, 2006):

(1) TS blocks link directly and they share common edges of $\mathrm{M}^{\mathrm{H}}$ and $\mathrm{A}^{P}$ polyhedra and common vertices of $\mathrm{M}^{\mathrm{H}}, \mathrm{A}^{P}$ and Si polyhedra of $\mathrm{H}$ sheets belonging to two TS blocks.

(2) TS blocks link through common vertices of Ti octahedra, and the I block has one layer of cations $(m=1)$.

(3) TS blocks do not link directly, additional cations do not occur in the I space ( $m=0)$, and TS blocks are connected through hydrogen bonds of $\left(\mathrm{H}_{2} \mathrm{O}\right)$ groups at the $X^{P}$ sites.

(4) TS blocks do not link directly, and there are additional layers of cations, the I block, between adjacent TS blocks $(m=1-6)$.

There are seven other minerals in Group III: lamprophyllite, nabalamprophyllite, barytolamprophyllite, innelite, epistolite, vuonnemite and bornemanite, and they are listed in Table 10 . Except for innelite, these minerals contain an invariant core of the TS block, $\mathrm{M}_{2}^{\mathrm{H}} \mathrm{M}_{4}^{\mathrm{O}}\left(\mathrm{Si}_{2} \mathrm{O}_{7}\right)_{2} \mathrm{X}_{4}^{\mathrm{O}}$, $\mathrm{M}_{2}^{\mathrm{H}}=\mathrm{Ti}, \mathrm{Nb}$ and $\mathrm{M}_{4}^{\mathrm{O}}=\mathrm{Na}_{3} \mathrm{Ti}$ (for innelite, $\mathrm{M}_{4}^{\mathrm{O}}=$ $\mathrm{Na}_{2} \mathrm{CaTi}$ ). In lamprophyllite, nabalamprophyllite, barytolamprophyllite, innelite, vuonnemite and bornemanite type 4 self-linkage of TS blocks occurs; in epistolite, type 3 occurs.

Nechelyustovite is the only Ti-silicate so far known where two types of self-linkage of TS blocks occur and these types of self-linkage are characteristic for Group III. In the crystal structure of nechelyustovite, two $\mathrm{TS}_{2}$ blocks are connected through hydrogen bonds of $\left(\mathrm{H}_{2} \mathrm{O}\right)$ groups at the $X^{P}$ sites (Figs $4 c, 5 a$ ) as in epistolite (Sokolova and Hawthorne, 2004) (Fig. 5b). The chemical compositions of both $M^{\mathrm{H}}$ and $A^{P}$ sites are identical in nechelyustovite and epistolite, a Nb-dominant ${ }^{[6]} M^{\mathrm{H}}$ site and an ${ }^{[8]} A^{P}$ site halfoccupied by $\mathrm{Na}$.

There are two types of $\mathbf{I}$ block in nechelyustovite. The $\mathbf{I}_{1}$ block is of composition $\mathrm{A}^{P}(1+2)=$ $\left(\mathrm{Ba}_{1.12} \mathrm{Sr}_{0.44} \mathrm{~K}_{0.26} \square_{0.18}\right)$ a.p.f.u. and is topologically and chemically similar to the I block (BaK) in barytolamprophyllite (Fig. $5 c$ ). Note that the aggregate charge of the $\mathbf{I}_{1}$ block is +3.38 , i.e. less than +4.00 for the ideal composition $\mathrm{Ba}_{2}$ but in good agreement with the charge of +3.00 in barytolamprophyllite.

The $\mathbf{I}_{2}$ block is of composition $\left(\square_{1.48} \mathrm{Ba}_{0.32} \mathrm{Sr}_{0.12} \mathrm{~K}_{0.08}\right)\left(\mathrm{H}_{2} \mathrm{O}\right)_{5}$. This is the first occurrence of an $\mathbf{I}$ block of this specific topology and chemistry (Figs 4b, 5a) in Ti-disilicate minerals and it does not currently have any structural analogues.

In the nechelyustovite structure, the inversion centre occurs within the $\mathbf{I}_{\mathbf{2}}$ blocks and between two $\mathrm{TS}_{2}$ blocks (as in epistolite) (Fig. $5 a$ ).

\section{Conclusions}

(1) In this work, we report the average crystal structure of nechelyustovite, ideally $\mathrm{Na}_{4} \mathrm{Ba}_{2} \mathrm{Mn}_{1.5}$ $\square 2.5 \mathrm{Ti}_{5} \mathrm{Nb}\left(\mathrm{Si}_{2} \mathrm{O}_{7}\right)_{4} \mathrm{O}_{4}(\mathrm{OH})_{3} \mathrm{~F}\left(\mathrm{H}_{2} \mathrm{O}\right)_{6}, \quad$ a $5.447(1)$

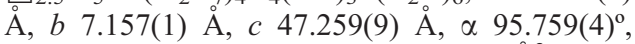
$\beta$ 92.136(4) $)^{\circ}, \gamma 89.978(4)^{\circ}, V 1831.7(4) \AA^{3}$, space group $P \overline{1}, Z=2, D_{\text {calc. }} 3.041 \mathrm{~g} \mathrm{~cm}^{-3}$.

(2) The structure of nechelyustovite is in accord with the general principles developed by Sokolova (2006). In nechelyustovite, the TS block exhibits linkage 1 and a stereochemistry typical for group-III TS-block minerals: two $\mathrm{H}$ sheets connect to the $\mathrm{O}$ sheet such that two $\left(\mathrm{Si}_{2} \mathrm{O}_{7}\right)$ groups link to the trans edges of a Ti octahedron of the $\mathrm{O}$ sheet. The average crystal structure of nechelyustovite does not support the structure models reported by Ferraris and Gula (2005).

(3) There are two TS blocks in nechelyustovite, $\mathrm{TS}_{1}$ and $\mathrm{TS}_{2}$, and their topology is identical except for the coordination of the peripheral $A^{P}$ sites. Each TS block has two $\mathrm{H}$ sheets, which differ in coordination of the $M^{\mathrm{H}}$ sites, [5] and [6], occupied by $\mathrm{Ti}$ and $\mathrm{Nb}$. In the $\mathrm{H}$ sheets, the peripheral $A^{P}$ sites are occupied by $\mathrm{Ba}$ and $\mathrm{Na}$.

(4) In nechelyustovite, TS blocks link through hydrogen bonds between $\mathrm{H}_{2} \mathrm{O}$ groups located at the $X^{P}$ sites (as in epistolite) and alternate with (intermediate) I blocks. A layer of $\mathrm{Ba}$ atoms forms the first $\mathbf{I}_{\mathbf{1}}$ block. The second $\mathbf{I}_{\mathbf{2}}$ block consists of two layers of [8]-coordinated polyhedra occupied by $\mathrm{Ba}$ at $\sim 24 \%$ and $\mathrm{H}_{2} \mathrm{O}$ groups.

(5) TS and I blocks alternate along $c$ in the crystal structure of nechelyustovite constituting a sequence of four TS blocks and three I blocks per the $c$ cell-parameter: $\mathrm{TS}_{2}-\mathbf{I}_{1}-\mathrm{TS}_{1}-\mathbf{I}_{2}-\mathrm{TS}_{1}$ $-\mathbf{I}_{1}-\mathrm{TS}_{2}$.

\section{Acknowledgements}

We thank Luca Bindi and Mark Welch for their comments on this paper. We are very grateful to Renato and Adriana Pagano, Milan, Italy, who provided a sample of nechelyustovite from their mineral collection (Collezione Mineralogica, sample \#10161). FC was supported by funding by CNR-IGG through the project TAP01.004. 


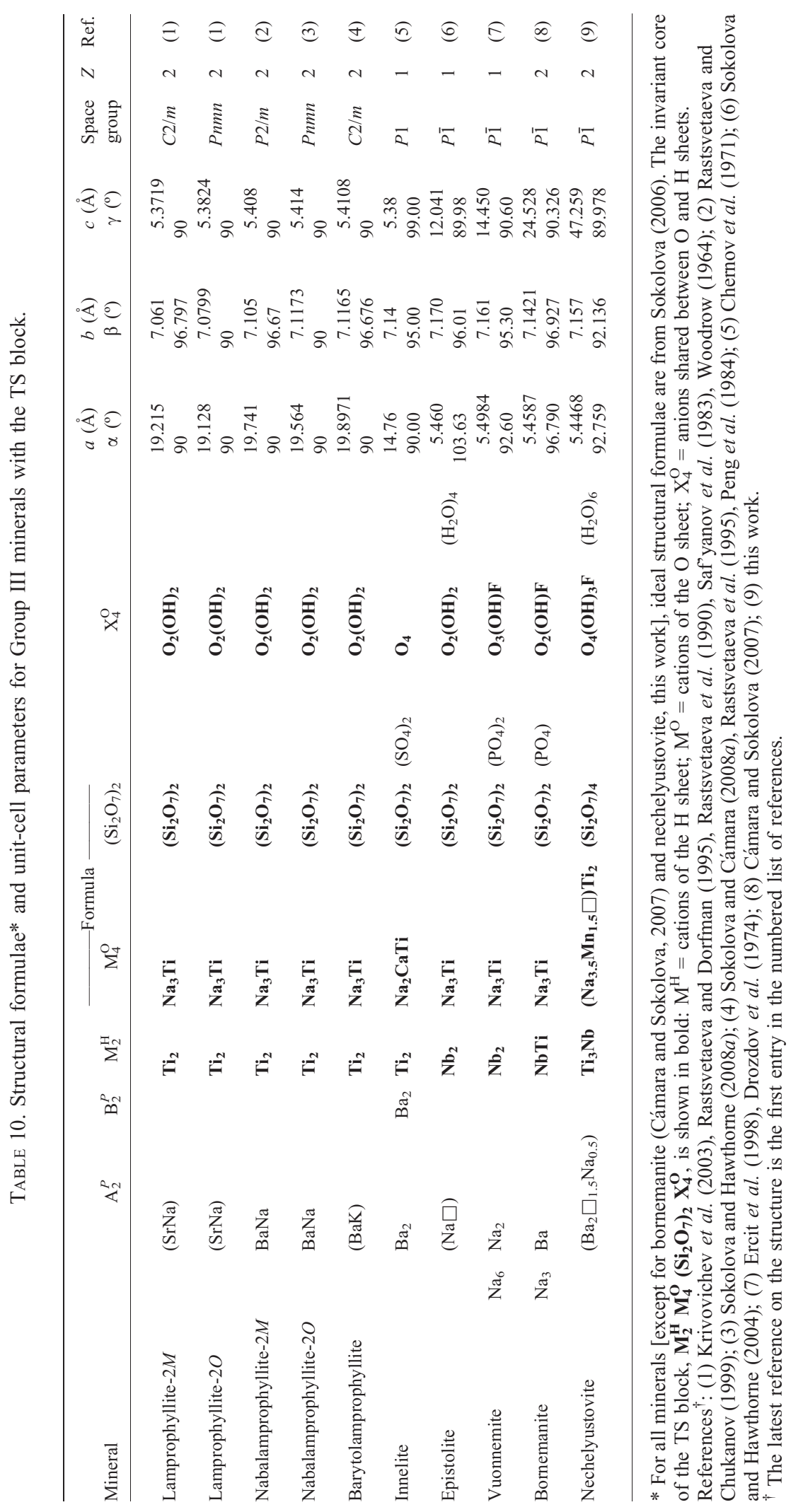




\section{References}

Brown, I.D. (1981) The bond-valence method: an empirical approach to chemical structure and bonding. Pp. 1-30 in: Structure and Bonding in Crystals II (M. O'Keeffe and A. Navrotsky, editors). Academic Press, New York.

Cámara, F. and Sokolova, E. (2007) From structure topology to chemical composition. VI. Titanium silicates: the crystal structure and crystal chemistry of bornemanite, a group-III Ti-disilicate mineral. Mineralogical Magazine, 71, 593-610.

Cámara, F., Sokolova, E., Hawthorne, F.C. and Abdu, Y. (2008) From structure topology to chemical composition. IX. Titanium silicates: revision of the crystal chemistry of lomonosovite and murmanite, GroupIV minerals. Mineralogical Magazine, 72, 1207-1228.

Chernov, A.N., Ilyukhin, V.V., Maksimov, B.A. and Belov, N.V. (1971) Crystal structure of innelite, $\mathrm{Na}_{2} \mathrm{Ba}_{3}(\mathrm{Ba}, \mathrm{K}, \mathrm{Mn})(\mathrm{Ca}, \mathrm{Ba}) \mathrm{Ti}\left(\mathrm{TiO}_{2}\right)_{2}\left(\mathrm{Si}_{2} \mathrm{O}_{7}\right)_{2}\left(\mathrm{SO}_{4}\right)_{2}$. Soviet Physics Crystallography, 16, 65-69.

Drozdov, Yu.N., Batalieva, N.G., Voronkov, A.A. and Kuz'min, E.A. (1974) Crystal structure of $\mathrm{Na}_{11} \mathrm{Nb}_{2} \mathrm{TiSi}_{4} \mathrm{P}_{2} \mathrm{O}_{25}$ F. Soviet Physics Doklady, 19, 258-259.

Ercit, T.S., Cooper, M.A. and Hawthorne, F.C. (1998) The crystal structure of vuonnemite, $\mathrm{Na}_{11} \mathrm{Ti}^{4+} \mathrm{Nb}_{2}\left(\mathrm{Si}_{2} \mathrm{O}_{7}\right)_{2}\left(\mathrm{PO}_{4}\right)_{2} \mathrm{O}_{3}(\mathrm{~F}, \mathrm{OH})$, a phosphatebearing sorosilicate of the lomonosovite group. The Canadian Mineralogist, 36, 1311-1320.

Ferraris, G. and Gula, A. (2005) Polysomatic aspects of microporous materials - heterophyllosilicates, palysepioles and rhodesite-related structures. Pp. 69-104 in: Micro and Mesoporous Mineral Phases (G. Ferraris and $\mathrm{S}$ Merlino, editors). Reviews in Mineralogy and Geochemistry, 57. Mineralogical Society of America, Chantilly, Virginia, USA.

Ferraris, G., Pushcharovsky, D.Yu., Zubkova, N.V. and Pekov, I.V. (2001) The crystal structure of delindeite, $\quad \mathrm{B} \mathrm{a}_{2}\left\{(\mathrm{Na}, \mathrm{K}, \square)_{3}(\mathrm{~T} \mathrm{i}, \mathrm{Fe})\right.$ $\left.\left[\mathrm{Ti}_{2}(\mathrm{O}, \mathrm{OH})_{4} \mathrm{Si}_{4} \mathrm{O}_{14}\right]\left(\mathrm{H}_{2} \mathrm{O}, \mathrm{OH}\right)_{2}\right\}$, a member of the mero-plesiotype bafertisite series. The Canadian Mineralogist, 39, 1307-1316.

Ferraris, G., Makovicky, E. and Merlino, S. (2004) Application of modularity to structure description and modeling. Pp. 227-279 in: Crystallography of Modular Materials. Oxford University Press, New York.

International Tables for X-ray Crystallography (1992) V.C. Dordrecht, Kluwer Academic Publishers, The Netherlands.

Khomyakov, A.P. (1995) Mineralogy of Hyperagpaitic Alkaline Rocks. Clarendon Press, Oxford, U.K.

Krivovichev, S.V., Armbruster, T., Yakovenchuk, V.N., Pakhomovsky, Ya. A. and Men'shikov, Yu. P. (2003) Crystal structures of lamprophyllite-2M and
lamprophyllite-2O from the Lovozero alkaline massif, Kola peninsula, Russia. European Journal of Mineralogy, 15, 711-718.

Nèmeth, P. (2004) Characterization of new mineral phases belonging to the heterophyllosilicate series. Doctorate Dissertation, Dipartimento di Scienze Mineralogiche e Petrologiche, Università di Torino, Italy.

Nèmeth, P., Ferraris, G., Dódony, I., Radnóczi, G. and Khomyakov, A.P. (2004) Models of the modular structures of two new heterophyllosilicates related to bornemanite and barytolamprophyllite. Acta Crystallographica A, 60, s196.

Nèmeth, P., Khomyakov, A.P., Ferraris, G. and Men'shikov, Yu.P. (2009) Nechelyustovite, a new heterophyllosilcate mineral, and new data on bykovaite: a comparative TEM study. European Journal of Mineralogy, 21, 251-260.

Peng, Z., Zhang, J. and Shu, J. (1984) The crystal structure of barytolamprophyllite and orthorhombic lamprophyllite. Kexure Tongbao, 29, 237-241.

Pouchou, J.L. and Pichoir, F. (1985) 'PAP' $\varphi(\rho Z)$ procedure for improved quantitative microanalysis. Pp. 104-106 in: Microbeam Analysis (J.T. Armstrong, editor). San Francisco Press, San Francisco, California, USA.

Rastsvetaeva, R.K. and Chukanov, N.V. (1999) Crystal structure of a new high-barium analogue of lamprophyllite with a primitive unit cell. Doklady Chemistry, 368(4-6), 228-231.

Rastsvetaeva, R.K. and Dorfman, M.D. (1995) Crystal structure of Ba-lamprophyllite in the isomorphous lamprophyllite-barytolamprophyllite series. Crystallography Reports, 40, 951-954.

Rastsvetaeva, R.K., Sokolova, M.N. and Gusev, A.I. (1990) Refinement of the crystal structure of lamprophyllite. Mineralogicheskii Zhurnal, 12(5), 25-28. (in Russian).

Rastsvetaeva, R.K., Evsyunin, V.G. and Konev, A.A. (1995) Crystal structure of K-barytolamprophyllite. Crystallography Reports, 40, 472-474.

Saf'yanov, Y.N., Vasil'eva, N.O., Golovachev, V.P., Kuz'min, E.A. and Belov, N.V. (1983) Crystal structure of lamprophyllite. Soviet Physics Doklady, 28, 207-209.

Shannon, R.D. (1976) Revised effective ionic radii and systematic studies of interatomic distances in halides and chalcogenides. Acta Crystallographica A, 32, $751-767$.

Sheldrick, G.M. (1997) SHELX-97: Program for the solution and refinement of crystal structures. Siemens Energy and Automation, Madison, Wisconsin, USA.

Sheldrick, G.M. (1998) SADABS User Guide, University of Göttingen, Germany.

Sokolova, E. (2006) From structure topology to 


\section{CRYSTAL STRUCTURE AND CRYSTAL CHEMISTRY OF NECHELYUSTOVITE}

chemical composition. I. Structural hierarchy and stereochemistry in titanium disilicate minerals. The Canadian Mineralogist, 44, 1273-1330.

Sokolova, E. and Cámara, F. (2007) From structure topology to chemical composition. II. Titanium silicates: revision of the crystal structure and chemical formula of delindeite. The Canadian Mineralogist, 45, 1247-1261.

Sokolova, E. and Cámara, F. (2008a) From structure topology to chemical composition. III. Titanium silicates: crystal chemistry of barytolamprophyllite. The Canadian Mineralogist, 46, 403-412.

Sokolova, E. and Cámara, F. (2008b) From structure topology to chemical composition. VIII. Titanium silicates: the crystal structure and crystal chemistry of mosandrite from type locality of Låven (Skådön), Langesundsfjorden, Larvik, Vestfold, Norway. Mineralogical Magazine, 72, 887-897.

Sokolova, E. and Hawthorne, F.C. (2001) The crystal chemistry of the $\left[\mathrm{M}_{3} \mathrm{O}_{11-14}\right]$ trimeric structures: from hyperagpaitic complexes to saline lakes. The Canadian Mineralogist, 39, 1275-1294.

Sokolova, E. and Hawthorne, F.C. (2004) The crystal chemistry of epistolite. The Canadian Mineralogist,
42, 797-806.

Sokolova, E. and Hawthorne, F.C. (2008a) From structure topology to chemical composition. IV. Titanium silicates: the orthorhombic polytype of nabalamprophyllite from Lovozero massif, Kola Peninsula, Russia. The Canadian Mineralogist, 46, 1469-1477.

Sokolova, E. and Hawthorne, F.C. (2008b) From structure topology to chemical composition. V. Titanium silicates: the crystal chemistry of nacareniobsite-(Ce). The Canadian Mineralogist, 46, 1493-1502.

Sokolova, E., Hawthorne, F.C. and Khomyakov, A.P. (2005) Polyphite and sobolevite: revision of their crystal structures. The Canadian Mineralogist, 43, $1527-1544$.

Sokolova, E., Cámara, F., Hawthorne, F.C. and Abdu, Y. (2009) From structure topology to chemical composition. VII. Titanium silicates: the crystal structure and crystal chemistry of jinshajiangite. European Journal of Mineralogy, 21, 871-883.

Woodrow, P.J. (1964) Crystal structure of lamprophyllite. Nature, 204, 375. 
